NPEL National Renewable Energy Laboratory

\title{
Trends in Utility Green Pricing Programs (2004)
}

Technical Report NREL/TP-620-38800

October 2005

Lori Bird and Elizabeth Brown

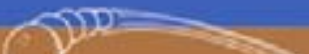




\section{Trends in Utility Green Pricing Programs (2004)}

\section{Lori Bird and Elizabeth Brown}

Prepared under Task No. ASG5.1003

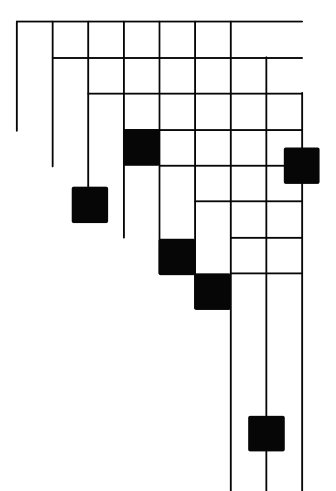

National Renewable Energy Laboratory

1617 Cole Boulevard, Golden, Colorado 80401-3393

303-275-3000 • www.nrel.gov

Operated for the U.S. Department of Energy

Office of Energy Efficiency and Renewable Energy

by Midwest Research Institute • Battelle

Contract No. DE-AC36-99-G010337 


\section{NOTICE}

This report was prepared as an account of work sponsored by an agency of the United States government. Neither the United States government nor any agency thereof, nor any of their employees, makes any warranty, express or implied, or assumes any legal liability or responsibility for the accuracy, completeness, or usefulness of any information, apparatus, product, or process disclosed, or represents that its use would not infringe privately owned rights. Reference herein to any specific commercial product, process, or service by trade name, trademark, manufacturer, or otherwise does not necessarily constitute or imply its endorsement, recommendation, or favoring by the United States government or any agency thereof. The views and opinions of authors expressed herein do not necessarily state or reflect those of the United States government or any agency thereof.

Available electronically at http://www.osti.gov/bridge

Available for a processing fee to U.S. Department of Energy and its contractors, in paper, from:

U.S. Department of Energy

Office of Scientific and Technical Information

P.O. Box 62

Oak Ridge, TN 37831-0062

phone: 865.576 .8401

fax: 865.576 .5728

email: mailto:reports@adonis.osti.gov

Available for sale to the public, in paper, from:

U.S. Department of Commerce

National Technical Information Service

5285 Port Royal Road

Springfield, VA 22161

phone: 800.553 .6847

fax: 703.605.6900

email: orders@ntis.fedworld.gov

online ordering: http://www.ntis.gov/ordering.htm 


\section{Acknowledgments}

This work was funded by the U.S. Department of Energy's (DOE) Office of Energy Efficiency and Renewable Energy (EERE). The authors wish to thank Linda Silverman and the EERE renewable energy technology programs for their support of this work. The authors also wish to thank Susan Innis of the Western Resource Advocates, Dan Lieberman of the Center for Resource Solutions, Diane Zipper of the Renewable Northwest Project, and Blair Swezey of NREL for their thoughtful review of the document; as well as Michelle Kubik of NREL for her editorial support. Finally, the authors thank the many utility contacts that provided the information summarized in this report, and Diane Zipper and Cindy Ryals of the Renewable Northwest Project for their assistance in collecting data from utilities in the Pacific Northwest. Additional information on green power market trends and activities can be found on the U.S. DOE's Green Power Network Web site (http://www.eere.energy.gov/greenpower/). 


\section{TABLE OF CONTENTS}

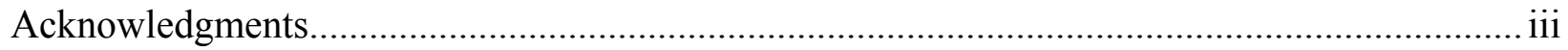

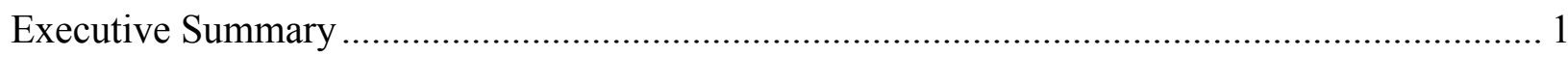

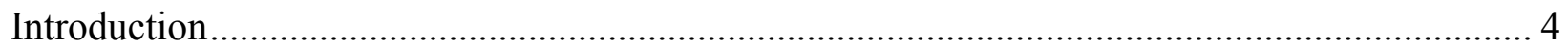

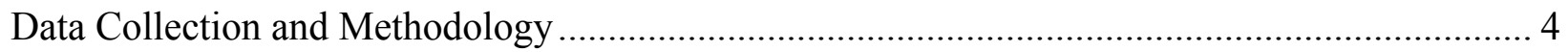

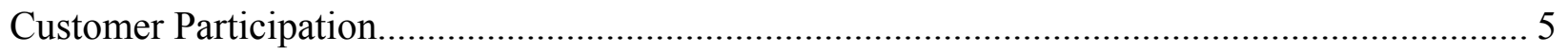

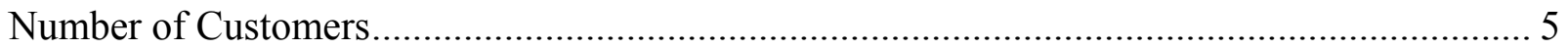

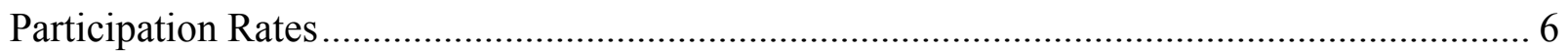

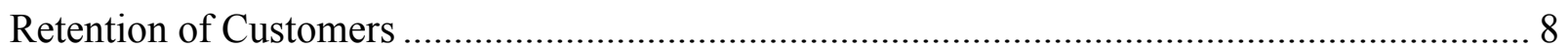

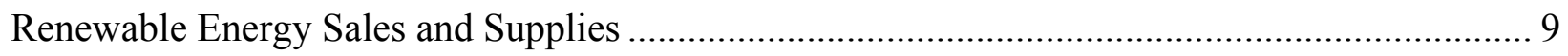

Green Power Sales and Revenues .................................................................................. 9

Green Energy Sales vs. Total Utility Sales...................................................................... 10

Ownership vs. Purchases of Supplies ............................................................................ 10

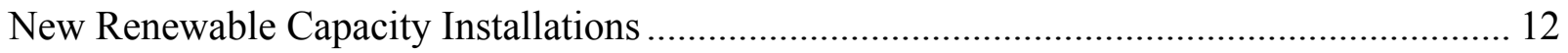

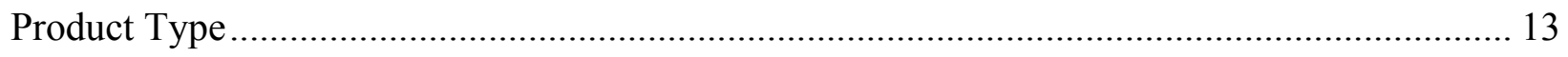

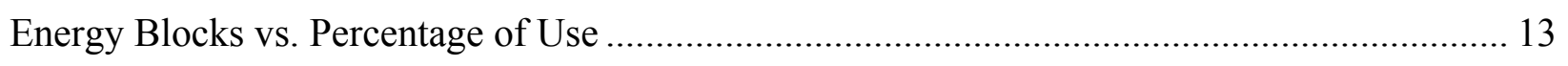

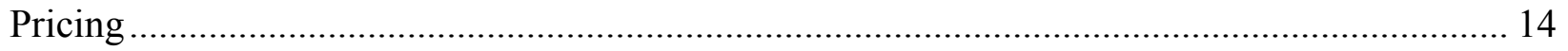

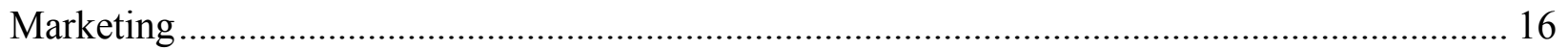

Marketing and Administration Spending …………….................................................... 16

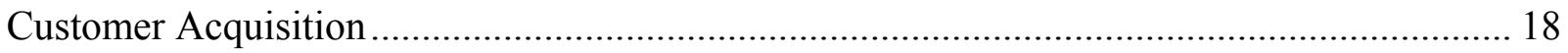

Marketing Techniques Employed................................................................................... 19

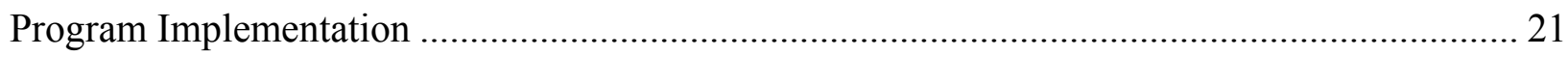

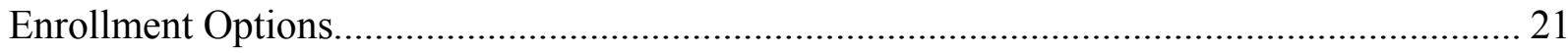

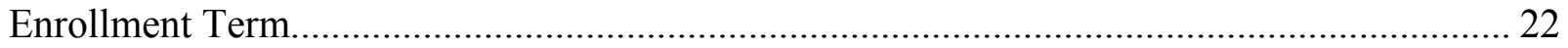

Program Evaluations and Market Research...................................................................... 22

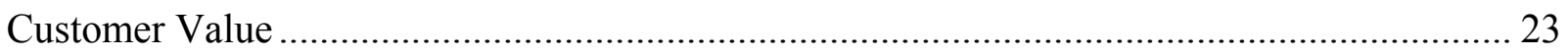

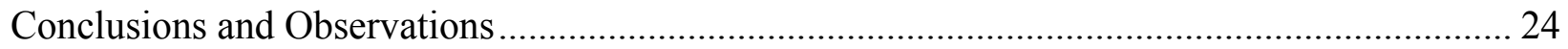

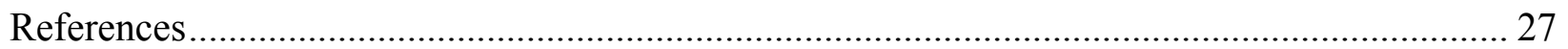

Appendix A: 2004 Utility Green Power Program Questionnaire …………………………....... 29

Appendix B: Utilities Offering Green Pricing Programs in 2004................................................ 33

Appendix C: Top 10 Utility Green Power Programs.............................................................. 34 


\section{LIST OF TABLES}

Table 1: Number of Participants in Utility Green Power Programs, 2004 ............................. 5

Table 2: Estimated Cumulative Number of Customers Participating in Utility Green Pricing

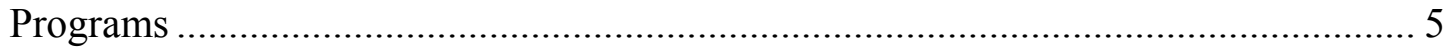

Table 3: Customer Participation Rates in Utility Green Pricing Programs ............................ 6

Table 4: Average Participation Rate by Age of Green Pricing Programs................................. 7

Table 5: Green Pricing Participation Rates by Utility Type ................................................ 8

Table 6: Fraction of Customers Dropping Out of Green Pricing Programs ........................... 8

Table 7: Sales of Renewable Energy through Utility Green Power Programs, 2004 ............... 9

Table 8: Annual Sales of Green Energy through Utility Green Pricing Programs (millions

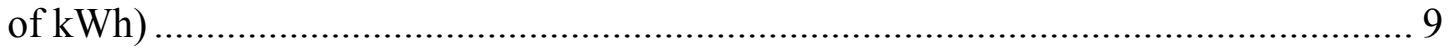

Table 9: Average Purchases of Green Energy Per Green Pricing Customer (kWh/year).......... 9

Table 10: Green Energy Sales as a Percent of Total Utility Electricity Sales in kWh .............. 10

Table 11: Residential Expenditures Per Month and Annual Program Revenues...................... 10

Table 12: Utility Procurement of Renewable Energy Supplies, 2004 .................................... 11

Table 13: REC Purchases by Utilities to Supply Green Pricing Programs .............................. 11

Table 14: Estimated Cumulative Capacity Supplying Utility Green Pricing Programs, 1999-2004.... 12

Table 15: New Renewables Capacity Supplying Green Pricing Programs, 2004 (Megawatts) 12

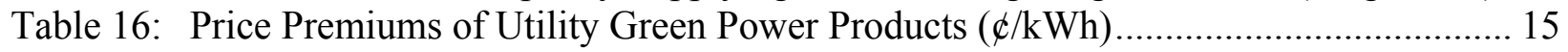

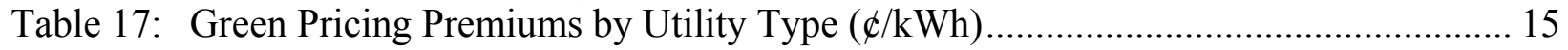

Table 18: Utility Expenditures on Marketing in 2004 (excluding staff time)........................... 16

Table 19: Utility Expenditures on Program Administration in 2004 (including staff time)...... 17

Table 20: Marketing and Administrative Expenditures as Percentage of Premium (2004) ....... 17

Table 21: Explanation of Costs Born by Nonparticipants ............................................... 18

Table 22: Residential Customer-Acquisition Costs by Year ............................................... 18

Table 23: Residential Customer-Acquisition Costs by Utility Size....................................... 19

Table 24: Marketing Techniques Used by Utilities ............................................................. 20

Table 25: Number of Marketing Techniques Used by Utilities (2004) ................................. 21

Table 26: Methods of Enrolling in Green Pricing Programs ............................................ 21

Table 27: Enrollment Term by Customer Segment ............................................................. 22

Table 28: Methods of Providing Additional Program Benefits ............................................. 24

Table B-1: Utilities Offering Green Pricing Programs in 2004 ............................................. 33

Table C-1: Green Pricing Program Renewable Energy Sales (as of December 2004)................ 34

Table C-2: Total Number of Customer Participants (as of December 2004) ............................ 35

Table C-3: Customer Participation Rate (as of December 2004) ........................................... 36

Table C-4: Price Premium Charged for New, Customer-Driven Renewable Power (as of

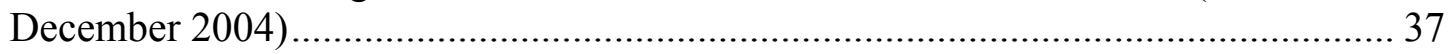

\section{LIST OF FIGURES}

Figure 1: Types of Green Pricing Programs .................................................................. 13

Figure 2: Utility Green Pricing Program Premiums (Energy-Based Programs Only) .............. 14

Figure 3: Utility Customer-Acquisition Costs (2004) ....................................................... 19 


\section{Executive Summary}

In the early 1990s, only a handful of utilities offered their customers a choice of purchasing electricity generated from renewable energy sources. Today, nearly 600 utilities in regulated electricity markets - or almost $20 \%$ of all utilities nationally - provide their customers a "green power" option. Because some utilities offer programs in conjunction with cooperative associations or other publicly owned power entities, the number of distinct programs totals about 125. Through these programs, more than 40 million customers spanning 34 states have the ability to purchase renewable energy to meet some portion or all of their electricity needs - or make contributions to support the development of renewable energy resources. Typically, customers pay a premium above standard electricity rates for this service.

This report presents year-end 2004 data on utility green pricing programs, and examines trends in consumer response and program implementation over time. The data in this report, which were obtained via a questionnaire distributed to utility green pricing program managers, can be used by utilities as benchmarks by which to gauge the success of their green power programs.

At the end of 2004, about $700 \mathrm{MW}$ of new renewable energy capacity was serving customers participating in utility green pricing programs, with another $225 \mathrm{MW}$ planned. Thus, green pricing continues to be a viable strategy for supporting the development of new renewable energy sources. Nevertheless, current success can be attributed to a relatively small number of programs. Continued industry growth will depend largely on whether consumer access to green pricing spreads beyond the one-fifth of utilities that currently offer programs and whether the success of the top-performing programs can be duplicated by other utilities. Additional challenges include retaining existing program participants as well as attracting new nonresidential customers, particularly in light of increased competition from REC marketers.

The following is a summary of key findings from this analysis.

\section{Consumer Response}

- In 2004, sales of renewable energy through utility green pricing programs continued to exhibit strong growth, increasing $43 \%$ to a total of nearly 2 billion kilowatt-hours $(\mathrm{kWh})$, following annual growth rates of 44\% in 2003 and 56\% in 2002. This growth has been driven by increases in the number of customers purchasing green power as well as larger purchases by nonresidential customers. While a relatively small number of programs still account for the majority of green pricing sales, the fraction attributed to the top 10 programs dropped to $70 \%$ in 2004 from $85 \%$ in 2003 .

- The number of customers purchasing green power also increased, but at a slower pace than sales. At the end of 2004, about 330,000 customers participated in utility green pricing programs in regulated markets, including about 8,000 nonresidential customers, which represented an increase of $25 \%$ from customer participants in 2003 . The top 10 programs accounted for $63 \%$ of participants, down from $75 \%$ in 2003 .

- Average participation rates in green pricing programs remained steady at $1.3 \%$, consistent with rates reported for the past several years. The top 10 utility green pricing programs showed some improvement, however, with two programs exceeding the $10 \%$ participation threshold and one reaching nearly $15 \%$. 
- The fraction of customers dropping out of green pricing programs averaged about $10 \%$ in 2004, up from $7 \%$ in 2003 , and $4 \%$ in 2002.

\section{Renewable Energy Supplies}

- In 2004 , about $25 \%$ of utilities owned the renewable energy-generation sources used to supply a significant portion of the energy sold to their green pricing customers, down from about $40 \%$ in 2003 . The remainder purchase renewable power or renewable energy certificates (RECs) from third parties to supply their programs.

- The use of RECs to supply green pricing programs continued to climb, with utilities purchasing more than 700 million $\mathrm{kWh}$ of RECs to serve green pricing customers in 2004 , nearly a $70 \%$ increase from 2003 . In fact, RECs represented nearly $40 \%$ of all green pricing sales in 2004.

- At the end of 2004, about $700 \mathrm{MW}$ of renewable energy capacity was used to supply green pricing programs, with another $225 \mathrm{MW}$ planned.

\section{Pricing and Revenues}

- The average price premium charged for green power through green pricing programs continued to decline, falling to $2.45 \% / \mathrm{kWh}$ in 2004 from $2.62 \notin / \mathrm{kWh}$ in 2003 . Since 2000, the premium has declined about $8 \%$ per year, on average. Consistent with experience in previous years, investor-owned utilities exhibited slightly higher than average price premiums than public or cooperative utilities.

- Of the utilities that reduced their price premiums during 2004, most attributed the reduction to the exemption of green power customers from higher fossil fuel charges or the ability to renegotiate power purchase contracts at lower rates.

- A handful of programs offer lower price premiums to large, nonresidential purchasers.

- In 2004, utilities collected an estimated $\$ 32$ million in revenues from green pricing programs.

- On average, residential customers paid a little more than $\$ 5$ per month for green power through utility programs, consistent with data from previous years.

\section{Marketing}

- As might be expected, utility expenditures on marketing and administration for green power programs vary by utility size. Utilities with more than 500,000 customers reported a wide range of marketing expenditures, with $30 \%$ spending less than $\$ 50,000$ and nearly $60 \%$ spending more than $\$ 100,000$. Only four utilities, all top performers, ${ }^{1}$ reported spending more than $\$ 250,000$ on marketing in 2004 and top performers represented $73 \%$ of utilities that spent more than $\$ 100,000$. Utilities reported similar levels of expenditures for program administration; however, a number of the top performers reported spending less on administration than marketing.

- Utilities reported a median cost of acquiring new residential customers of $\$ 30$, consistent with data from previous years, while the top performers reported a median of $\$ 40$.

- In 2004, utilities reported spending a median of $9 \%$ of the price premium (program revenues) on marketing and administration, compared to 5\% in 2003.

\footnotetext{
1 "Top performers" are defined as the top 10 ranked utilities by total number of program participants, customer participation rate, or green power sales.
} 
- Nearly two-thirds of utilities reported that nonparticipants pay some portion of green pricing program costs. The most common reason is that the utility spreads some of the marketing and administrative costs among all ratepayers.

- On average, utilities used at least four different marketing techniques to publicize their green pricing program in 2004, while the top performers used an average of seven.

- The marketing techniques that utilities ranked as most effective include direct mail, direct sales, publicity, Web marketing, and other (door-to-door sales, bangtails, and print ads). Interestingly, the techniques that receive the highest scores for effectiveness from program managers are not necessarily the most commonly used.

- Compared to all programs, the top performers more commonly use techniques such as Web marketing, direct mail, direct sales, publicity, partnerships with environmental organizations, television ads, retail partnerships, and community challenges.

\section{Program Implementation}

- Utilities ranked the following as among the most effective enrollment methods: check boxes on the utility bill, mail-in cards, and other strategies which utilities listed (enrolling customers through account representatives, retail partners, bill inserts, or phone contractors).

- Only about one-third of utilities impose a minimum subscription requirement on their green pricing customers, with one year being the most common contract requirement.

- Nearly two-thirds of utilities reported that they had conducted customer research to aid in the design or implementation of their green pricing programs; but only $46 \%$ reported performing a program evaluation, compared to $65 \%$ of the top performers.

- It is more common for top performing utilities to provide additional program benefits, such as recognizing business customers in local media, recognizing other customers with plaques, providing decals for display in store windows, providing discounts or promotions at local businesses, protecting customers from fuel cost increases, and providing energy efficiency products. The top performers reported providing an average of four such benefits to program participants compared to two for all programs. 


\section{Introduction}

Utilities first began offering consumers a choice of purchasing electricity generated from renewable energy sources in the early 1990s. Since then, the number of U.S. utilities offering green pricing programs has steadily grown. Today, nearly 600 utilities in regulated electricity markets - or about $20 \%$ of all utilities nationally - offer their customers green power options. Because some of these utilities offer programs in conjunction with cooperative associations or other public power entities, the number of distinct programs is about 125 . Through these programs, more than 40 million customers spanning 34 states have the ability to purchase renewable energy to meet some portion or all of their electricity needs, or make contributions to support the development of renewable energy resources. Typically, customers must pay a premium above standard electricity rates for this service.

With about one-fifth of utilities now offering green power options to their customers, there is sufficient experience nationwide to assess industry trends and the potential contribution of these voluntary programs to overall renewable energy development. Since 1999, the National Renewable Energy Laboratory (NREL) has compiled data on utility green pricing programs on an annual basis. Initially, the data covered consumer response and program-design features, such as participation and retention rates, price premiums, program structures, enrollment requirements, and new renewable energy capacity installed to supply green pricing programs. ${ }^{2}$ Beginning in 2002, NREL added data on marketing and program implementation, covering areas such as customer-acquisition costs, marketing strategies and budgets, program evaluation efforts, procurement of supplies, and methods of enrolling and providing value to customers. The 2002 and 2003 data are presented in detail in Bird et al. (2004) and Bird and Cardinal (2004), respectively. ${ }^{3}$

This report presents detailed data compiled for year-end 2004, and examines trends in consumer response and program implementation since 1999. The data provided in this report can also be used by utilities to benchmark the success of their green pricing programs.

\section{Data Collection and Methodology}

The information presented in this report is based on data provided to the NREL by utilities operating green pricing programs. In 2004, a questionnaire was distributed via e-mail to 144 green pricing program managers representing 124 individual green pricing programs (see Appendix A for the questionnaire, and Appendix B for a list of utilities that offer green pricing programs). In a few instances, the questionnaire was distributed to several distribution utilities that participate in a single green pricing program offered through a generation and transmission cooperative or public power supplier. We did this because some power suppliers do not collect data from participating distribution utilities or are not able to provide data on marketing and program implementation. Also in 2004, we collected data for the first time from a number of utility programs offered in conjunction with third-party marketers in states that have implemented retail competition. These responses were only included in the estimates of total utility green power customers and sales. Five programs were found to be inactive or

\footnotetext{
2 The results are summarized in Swezey and Bird 1999; 2000.

${ }^{3}$ Data on the entire green power market, including nonutility programs are summarized in Bird and Swezey (2004).
} 
discontinued, yielding a pool of 139 potential responses. ${ }^{4}$ Responses were received for 97 programs, yielding an overall active program response rate of $70 \%$. The response rate, excluding programs offered in competitive electricity markets, was also $70 \%$. Where possible, data gaps were filled with information obtained from utility Web sites, follow-up phone calls, and published reports (Washington CTED and UTC 2002, 2003, 2004), as well as data received in previous years.

\section{Customer Participation}

\section{Number of Customers}

At the end of 2004, an estimated 361,000 customers were participating in utility green power programs nationally, including programs offered in regulated and restructured electricity markets (Table 1). ${ }^{5}$ The top 10 utility programs for participation ${ }^{6}$ accounted for $63 \%$ of all participants (Appendix C). Of total program participants in 2004, utilities reported that about 30\% were new.

Table 1: Number of Participants in Utility Green Power Programs, 2004

\begin{tabular}{|l|r|}
\hline Utility Green Pricing Programs in Regulated Markets & 331,800 \\
\hline Utility Programs in Restructured Markets & 29,400 \\
\hline Total & 361,200 \\
\hline
\end{tabular}

Table 2 presents the number of customers participating in utility green pricing programs offered in traditionally regulated electricity markets since 1999. From 1999 to 2004, the number of customer participants increased nearly fivefold, with an annual average growth rate of $38 \%$.

Table 2: Estimated Cumulative Number of Customers Participating in Utility Green Pricing Programs

\begin{tabular}{|l|c|c|c|c|c|c|}
\hline Customer Segment & $\mathbf{1 9 9 9}$ & $\mathbf{2 0 0 0}$ & $\mathbf{2 0 0 1}$ & $\mathbf{2 0 0 2}$ & \multicolumn{1}{c|}{$\mathbf{2 0 0 3}$} & \multicolumn{1}{c|}{$\mathbf{2 0 0 4}$} \\
\hline Residential & $\mathrm{n} / \mathrm{a}^{*}$ & 131,000 & 166,300 & 224,500 & 258,700 & 323,700 \\
\hline Nonresidential & $\mathrm{n} / \mathrm{a}^{*}$ & 1,700 & 2,500 & 3,900 & 6,500 & 8,100 \\
\hline Total & 66,900 & 132,700 & 168,800 & 228,400 & 265,000 & 331,800 \\
\hline$\%$ Annual Growth & $\mathrm{n} / \mathrm{a}$ & $98 \%$ & $27 \%$ & $35 \%$ & $16 \%$ & $25 \%$ \\
\hline$\%$ Nonresidential & $\mathrm{n} / \mathrm{a}$ & $1.3 \%$ & $1.5 \%$ & $1.7 \%$ & $2.4 \%$ & $2.5 \%$ \\
\hline *Information on customer segments was not collected in 1999. \\
\hline
\end{tabular}

\footnotetext{
${ }^{4}$ Two of these programs were pilot programs that are being redesigned and will be re-launched in 2005 .

${ }^{5}$ NREL obtained consumer response data for about $70 \%$ of utility green pricing programs in 2004 , including all of the major programs. The remaining programs, which are smaller in size, do not have a large impact on overall participant numbers.

${ }^{6}$ NREL issues four different Top 10 lists based on total sales of renewable energy to program participants, total number of customer participants, customer participation rates, and the premium charged to support new renewables development. These lists can be found at http://www.eere.energy.gov/greenpower/markets/pricing.shtml?page=3.
} 
Table 2 delineates residential and nonresidential customer participation in utility green pricing programs over time. During 2004, the number of residential and nonresidential customers grew at approximately the same rate of $25 \%$. Growth in nonresidential customers slowed in 2004, compared to $66 \%$ during 2003. In previous years, the number of commercial and industrialsector participants increased more rapidly than residential participants, at least partly because of increased marketing targeting the nonresidential sector. The even growth rates among customer segments in 2004 may indicate a shift back toward a residential focus—or reflect increased competition from competitive renewable energy certificate (REC) marketers. ${ }^{7}$

In 2004, only two programs had sold all of the green power available under the program and were no longer actively seeking new customers, down from eight fully subscribed programs in 2003. One of these programs maintained a waiting list.

\section{Participation Rates}

At the end of 2004, the average rate of participation in utility green pricing programs among eligible utility customers was $1.3 \%$, with a median of $1.0 \%$ (Table 3); these industry-wide rates have shown very little change in recent years. The 10 programs with the highest participation rates achieved participation rates of between $4 \%$ and $15 \%$ in 2004 , compared to $4 \%$ and $11 \%$ in 2003, and 3\% to 6\% in 2002 (Appendix C). ${ }^{8}$ Although the upper end of the range is increasing over time, average participation rates remain well below penetration rates predicted by utility market research surveys (Farhar 1999).

Some possible explanations for the lack of improvement in overall participation rates include: 1) a general lack of awareness among customers, 2) lack of sustained marketing efforts on the part of some utilities, 3) a discrepancy between what customers report in surveys and what they actually do when presented with an option, 4) poor value propositions or product quality, and 5) the addition of new programs each year, which are averaged with the performance of more established programs (Holt and Holt, 2004; Swezey and Bird, 2001).

Table 3: Customer Participation Rates in Utility Green Pricing Programs

\begin{tabular}{|l|c|c|c|c|c|c|}
\hline $\begin{array}{l}\text { Participation } \\
\text { Rate }\end{array}$ & $\mathbf{1 9 9 9}$ & $\mathbf{2 0 0 0}$ & $\mathbf{2 0 0 1}$ & $\mathbf{2 0 0 2}$ & $\mathbf{2 0 0 3}$ & $\mathbf{2 0 0 4}$ \\
\hline Average & $0.9 \%$ & $1.2 \%$ & $1.3 \%$ & $1.2 \%$ & $1.2 \%$ & $1.3 \%$ \\
\hline Median & $0.8 \%$ & $0.7 \%$ & $0.7 \%$ & $0.8 \%$ & $0.9 \%$ & $1.0 \%$ \\
\hline Top 10 & $2.1 \%-$ & $2.6 \%-$ & $3.0 \%-$ & $3.0 \%-$ & $3.9 \%-$ & $3.8 \%-$ \\
programs & $4.7 \%^{*}$ & $7.3 \%$ & $7.0 \%$ & $5.8 \%$ & $11.1 \%$ & $14.5 \%$ \\
\hline "Data for April 2000
\end{tabular}

\footnotetext{
${ }^{7}$ RECs represent the environmental attributes of renewable energy generation and can be sold separately from commodity electricity. Sales by REC marketers have grown dramatically during the past several years.

${ }^{8}$ From 2000 to 2002 , the high end of the range declined because the utility with the highest participation rate (Moorhead Public Service) experienced an increase in its overall customer base, while the number of participants in its green pricing program remained steady. The program was fully subscribed in 2000, and the utility has not attempted to expand it.
} 
Data show a generally positive relationship between participation rates and program duration (Table 4). At the end of 2004, the average participation rate for programs that were at least 4 years old was $1.6 \%$, compared to $1.3 \%$ for all programs. When examining data for 2002 and earlier, Wiser et al. (2004) also found a positive and statistically significant relationship between participation rates and program duration, as well as significant participation impacts based on program design, implementation, and marketing. Based on the Wiser et al. report and data collected from program managers, we can postulate that program duration allows for increased learning regarding participant needs, effective program design, and marketing techniques that increase overall program participation.

Table 4: Average Participation Rate by Age of Green Pricing Programs

\begin{tabular}{|l|l|}
\hline All programs & $1.29 \%$ \\
\hline Programs at least 1 year old & $1.35 \%$ \\
\hline Programs at least 2 years old & $1.26 \%$ \\
\hline Programs at least 3 years old & $1.45 \%$ \\
\hline Programs at least 4 years old & $1.64 \%$ \\
\hline Note: based on 80 responses \\
\hline
\end{tabular}

Table 5 shows that across all utilities, the average participation rate for green pricing programs in 2004 for residential customers was $1.4 \%$ and $0.4 \%$ for nonresidential customers. Median participation rates were $1.0 \%$ and $0.2 \%$ for residential and nonresidential customers, respectively. The lower participation rates among nonresidential customers may be explained, in part, by the fact that some programs place less emphasis on the nonresidential sector. Also, nonresidential customers as a whole may be more price-sensitive and perhaps less willing to pay a premium than residential consumers.

Table 5 reveals differences in average participation rates among programs offered by investorowned utilities (IOUs), municipal or public utilities, and cooperatives; however, the differences narrow when the median rates are compared. Although IOU participation rates increased slightly from 2003, IOUs still reported the lowest average participation rates among all utility types. However, caution is advised in drawing conclusions based on these data. For example, after performing a statistical analysis of 2002 data, Wiser et al. (2004) found no evidence that utilityownership type influenced participation rates - but did find that smaller utilities tend to achieve higher participation rates. 
Table 5: Green Pricing Participation Rates by Utility Type

\begin{tabular}{|l|c|c|c|c|c|c|c|c|}
\hline & \multicolumn{2}{|c|}{$\begin{array}{c}\text { Number of } \\
\text { Utility } \\
\text { Type }\end{array}$} & \multicolumn{2}{|c|}{$\begin{array}{c}\text { Residential } \\
\text { Customers } \\
\text { Average/Median } \\
\text { Responses }\end{array}$} & \multicolumn{2}{c|}{$\begin{array}{c}\text { Nonresidential } \\
\text { Customers } \\
\text { Average/Median } \\
\%\end{array}$} & \multicolumn{2}{|c|}{$\begin{array}{c}\text { All Customers } \\
\text { Average/Median } \\
\%\end{array}$} \\
\hline & $\mathbf{2 0 0 3}$ & $\mathbf{2 0 0 4}$ & $\mathbf{2 0 0 3}$ & $\mathbf{2 0 0 4}$ & $\mathbf{2 0 0 3}$ & $\mathbf{2 0 0 4}$ & $\mathbf{2 0 0 3}$ & $\mathbf{2 0 0 4}$ \\
\hline All Utilities & 75 & 80 & $1.4 / 1.0$ & $1.4 / 1.1$ & $0.5 / 0.2$ & $0.4 / 0.2$ & $1.2 / 0.9$ & $1.3 / 1.0$ \\
\hline Coops. & 13 & 13 & $1.7 / 1.1$ & $1.7 / 1.2$ & $0.6 / 0.01$ & $0.6 / 0.1$ & $1.6 / 1.0$ & $1.5 / 1.0$ \\
\hline Public & 36 & 38 & $1.5 / 1.1$ & $1.6 / 1.1$ & $0.5 / 0.2$ & $0.5 / 0.2$ & $1.3 / 1.0$ & $1.4 / 0.8$ \\
\hline $\begin{array}{l}\text { Investor- } \\
\text { owned }\end{array}$ & 26 & 29 & $1.0 / 0.9$ & $1.1 / 1.0$ & $0.3 / 0.1$ & $0.3 / 0.1$ & $0.8 / 0.7$ & $1.0 / 0.9$ \\
\hline
\end{tabular}

\section{Retention of Customers}

In 2004, utilities reported that an average of $9.8 \%$ and a median of $8.8 \%$ of customers dropped out of green pricing programs. For the past three years, the average rate of attrition has been increasing (Table 6). While retention of participants is still high, the trend indicates that customer retention requires attention from program managers.

Historically, utilities that have reported higher-than-average turnover rates among green power customers cite high turnover among all utility customers; for example, several of these utilities have service territories that include large universities where high customer turnover is recurrent. One utility also cited particularly high attrition rates after announcing plans to build a new coalfired power plant, which regional environmental organizations opposed. And a few utilities have experienced higher-than-average decreases in enrollment as a result of general rate increases.

One effective strategy for reducing attrition is retaining customer participants in the program when they move within the utility service territory. Also, continuing to communicate the success and benefits of the program to consumers may help alleviate problems with attrition. Consumers may need to be reminded periodically of the value of the program and the impact that their expenditures have had. Finally, offering benefits such as exempting customers from fossil fuel cost increases may help retain customers.

Table 6: Fraction of Customers Dropping Out of Green Pricing Programs

\begin{tabular}{|r|r|r|r|}
\hline & $\mathbf{2 0 0 2}$ & $\mathbf{2 0 0 3}$ & $\mathbf{2 0 0 4}$ \\
\hline Median & $2.5 \%$ & $6.6 \%$ & $8.8 \%$ \\
\hline Average & $4.3 \%$ & $7.1 \%$ & $9.8 \%$ \\
\hline
\end{tabular}




\section{Renewable Energy Sales and Supplies}

\section{Green Power Sales and Revenues}

Collectively, utilities sold nearly 2 billion kilowatt-hours ( $\mathrm{kWh}$ ), or about 226 average megawatts (aMW), of green power to customers in 2004 (Table 7). The 10 top-performing green pricing programs represented $71 \%$ of total sales, with one program (Austin Energy) accounting for 17\% of all sales (Appendix C). Austin Energy's sales success stems from the fact that it allows customers to lock-in the price of green energy at a fixed rate for up to 10 years, which has been particularly popular among nonresidential customers. Overall, nonresidential customers represented only $2.5 \%$ of customers, but represented nearly one-third of total program sales.

Table 7: Sales of Renewable Energy through Utility Green Power Programs, 2004

\begin{tabular}{|l|r|}
\hline & million kWh \\
\hline Utility Green Pricing Programs in Regulated Markets & 1,839 \\
\hline Utility Programs in Restructured Markets & 136 \\
\hline Total & 1,975 \\
\hline
\end{tabular}

Table 8 presents sales of renewable energy through utility green pricing programs in regulated electricity markets over time. Green pricing program sales to all customer classes grew by $43 \%$ in 2004, compared with $44 \%$ in 2003 and $56 \%$ in 2002. The growth in sales can be attributed to the larger number of customers purchasing green power as well as larger purchases by nonresidential customers (Table 9). On average, residential customers purchased an average of about $4,000 \mathrm{kWh}$ of green power annually in 2004, while nonresidential customers purchased nearly $125,000 \mathrm{kWh}$.

Table 8: Annual Sales of Green Energy through Utility Green Pricing Programs (millions of kWh)

\begin{tabular}{|l|r|r|r|r|r|}
\hline & $\mathbf{2 0 0 0}$ & $\mathbf{2 0 0 1}$ & $\mathbf{2 0 0 2}$ & $\mathbf{2 0 0 3}$ & $\mathbf{2 0 0 4}$ \\
\hline Residential customers & --- & 400 & 661 & 874 & 1,295 \\
\hline Nonresidential customers & --- & 173 & 234 & 410 & 544 \\
\hline Total All customers & 454 & 573 & 895 & 1,284 & 1,839 \\
\hline$\%$ Annual Growth & --- & $26 \%$ & $56 \%$ & $44 \%$ & $43 \%$ \\
\hline \% Nonresidential & --- & $30 \%$ & $26 \%$ & $32 \%$ & $30 \%$ \\
\hline *Sales information for customer segments not available for 2000.
\end{tabular}

Table 9: Average Purchases of Green Energy Per Green Pricing Customer (kWh/year)

\begin{tabular}{|l|r|r|r|}
\hline & $\mathbf{2 0 0 2}$ & $\mathbf{2 0 0 3}$ & $\mathbf{2 0 0 4}$ \\
\hline Residential Customers & 2,990 & 5,040 & 3,970 \\
\hline Nonresidential Customers & 40,990 & 78,550 & 123,780 \\
\hline All Customers & 3,780 & 18,740 & 20,000 \\
\hline
\end{tabular}




\section{Green Energy Sales vs. Total Utility Sales}

Green energy sales still represent a small proportion of a utility company's overall energy sales. Table 10 shows that, on average, sales through green pricing programs represent about $0.4 \%$ of total utility electricity sales. Green power sales represent about $0.7 \%$ of residential electricity sales and $0.2 \%$ of nonresidential electricity sales. The most successful utility programs report green energy sales of about $3 \%$ of total electricity sales.

Table 10: Green Energy Sales as a Percent of Total Utility Electricity Sales in kWh

\begin{tabular}{|l|c|c|c|c|c|c|}
\hline & \multicolumn{3}{|c|}{2003} & \multicolumn{2}{c|}{2004} \\
\hline $\begin{array}{c}\text { Customer } \\
\text { Class }\end{array}$ & Average & Median & Range & Average & Median & Range \\
\hline Residential & $0.3 \%$ & $0.02 \%$ & $0.0 \%-3.6 \%$ & $0.7 \%$ & $0.4 \%$ & $0 \%-10.2 \%$ \\
\hline Nonresidential & $0.1 \%$ & $0.00 \%$ & $0.0 \%-2.9 \%$ & $0.2 \%$ & $0.02 \%$ & $0 \%-3.7 \%$ \\
\hline All customers & $0.2 \%$ & $0.04 \%$ & $0.0 \%-3.2 \%$ & $0.4 \%$ & $0.2 \%$ & $0 \%-3.2 \%$ \\
\hline
\end{tabular}

On average, residential customers spent $\$ 5.30$ per month to purchase or support green power through utility programs in 2004 , down slightly from $\$ 5.50$ in 2003 , but higher than $\$ 4.80$ in 2002 (Table 11).

Utility green pricing programs collected an estimated $\$ 32$ million in revenues from green power sales in 2004, up from $\$ 20$ million in 2003 (a 60\% increase) (Table 11). Green pricing program revenues are typically used to pay the above-market costs of renewables, as well as the costs of administering and marketing the program - although the treatment of the latter differs by utility (see discussion in the Marketing section and Holt and Holt 2004; Swezey and Bird 2001).

Table 11: Residential Expenditures Per Month and Annual Program Revenues

\begin{tabular}{|l|c|c|c|}
\hline & $\mathbf{2 0 0 2}$ & $\mathbf{2 0 0 3}$ & $\mathbf{2 0 0 4}$ \\
\hline Monthly residential expenditures on green power & $\$ 4.80$ & $\$ 5.50$ & $\$ 5.30$ \\
\hline Annual utility revenues from green power & $\$ 15$ million & $\$ 20$ million & $\$ 32$ million \\
\hline
\end{tabular}

\section{Ownership vs. Purchases of Supplies}

About $21 \%$ of utilities supply their green pricing programs entirely from their own renewable energy generation facilities, compared to $31 \%$ in 2003 (Table 12). Another $62 \%$ of utilities either purchase all of their power from an independent power generator or purchase renewable energy certificates (RECs) from a marketer or supplier. The remaining utilities use a combination of these approaches to supply their green power programs. Generally, the data show a movement away from project ownership and an increased reliance on REC purchases. Between 2003 and 2004, the fraction of utilities that purchased RECs for all of their green pricing program supplies 
increased from $18 \%$ to $30 \%$. In addition, the fraction of utilities that owned their own generation for any portion of program supplies dropped from nearly one-half to one-third.

Table 12: Utility Procurement of Renewable Energy Supplies, 2004

\begin{tabular}{|l|c|c|c|c|c|c|}
\hline & \multicolumn{2}{|c|}{$\begin{array}{c}\text { Utilities that } \\
\text { Own Generation }\end{array}$} & $\begin{array}{c}\text { Utilities that } \\
\text { Purchase } \\
\text { Power }\end{array}$ & \multicolumn{2}{c|}{$\begin{array}{c}\text { Utilities that } \\
\text { Purchase RECs }\end{array}$} \\
\hline Fraction of Supplies & $\mathbf{2 0 0 3}$ & $\mathbf{2 0 0 4}$ & $\mathbf{2 0 0 3}$ & $\mathbf{2 0 0 4}$ & $\mathbf{2 0 0 3}$ & $\mathbf{2 0 0 4}$ \\
\hline $\begin{array}{l}\text { For 100\% of program power } \\
\text { supplies }\end{array}$ & $31 \%$ & $21 \%$ & $32 \%$ & $32 \%$ & $18 \%$ & $30 \%$ \\
\hline $\begin{array}{l}\text { For at least 50\% of program power } \\
\text { supplies }\end{array}$ & $39 \%$ & $25 \%$ & $42 \%$ & $40 \%$ & $20 \%$ & $33 \%$ \\
\hline $\begin{array}{l}\text { For any fraction of program power } \\
\text { supplies }\end{array}$ & $49 \%$ & $33 \%$ & $47 \%$ & $48 \%$ & $24 \%$ & $36 \%$ \\
\hline Note: Percentages based on 74 responding programs in 2003, and 84 programs in 2004. \\
\hline
\end{tabular}

Collectively, utilities purchased more than 700 million $\mathrm{kWh}$ of RECs to serve green power customers in 2004, which represents $38 \%$ of all green power sold through utility green pricing programs (Table 13). RECs purchases grew by $69 \%$ in 2004, after a $300 \%$ increase between 2002 and 2003.

Table 13: REC Purchases by Utilities to Supply Green Pricing Programs

\begin{tabular}{|l|c|c|c|}
\hline & $\mathbf{2 0 0 2}$ & $\mathbf{2 0 0 3}$ & $\mathbf{2 0 0 4}$ \\
\hline $\begin{array}{l}\text { REC purchases by utilities for green } \\
\text { pricing programs (million } \mathrm{kWh} \text { ) }\end{array}$ & 103 & 419 & 707 \\
\hline $\begin{array}{l}\text { REC purchases as percent of total green } \\
\text { pricing sales }\end{array}$ & $11 \%$ & $33 \%$ & $38 \%$ \\
\hline
\end{tabular}

Data from 2004 also suggests that RECs are being used in wider geographic regions. In 2003, about three-quarters of utilities that supplied their programs with RECs were located in the Pacific Northwest. In 2004, only half of the utilities using RECs were in the Pacific Northwest. Utilities that reported purchasing RECs for some portion of their program supplies in 2004 covered nine states, including Arizona, California, Colorado, Florida, Idaho, Oregon, Utah, Vermont, and Washington. 


\section{New Renewable Capacity Installations}

The amount of new ${ }^{9}$ renewable energy capacity installed to serve green pricing programs has grown significantly during the past several years (Table 14). At the end of 2004, about $700 \mathrm{MW}$ of renewable energy capacity was used to supply utility green pricing programs, with nearly another $230 \mathrm{MW}$ planned (Table 15). ${ }^{10}$ This represented a $38 \%$ increase over the installed capacity supplying green pricing programs in 2003 . Wind, solar, and landfill gas are the renewable resources most commonly included in green pricing programs, with wind representing the largest portion of the total capacity — at the end of 2004, wind energy represented more than $80 \%$ of the installed capacity.

Table 14: Estimated Cumulative Capacity Supplying Utility Green Pricing Programs, 1999-2004

\begin{tabular}{|l|c|c|c|c|c|c|}
\hline & $\mathbf{1 9 9 9}$ & $\mathbf{2 0 0 0}$ & $\mathbf{2 0 0 1}$ & $\mathbf{2 0 0 2}$ & $\mathbf{2 0 0 3}$ & $\mathbf{2 0 0 4}$ \\
\hline Cumulative MW & 68 & 77 & 221 & 279 & 510 & 706 \\
\hline Annual Growth \% & -- & $14 \%$ & $188 \%$ & $26 \%$ & $83 \%$ & $38 \%$ \\
\hline
\end{tabular}

Table 15: New Renewables Capacity Supplying Green Pricing Programs, 2004 (Megawatts)

\begin{tabular}{|l|r|r|r|r|}
\hline Source & \multicolumn{2}{|c|}{ Installed } & \multicolumn{2}{c|}{ Planned } \\
\hline Wind & 584.0 & $82.8 \%$ & 139.7 & $61.1 \%$ \\
\hline Biomass & 76.3 & $10.8 \%$ & 57.5 & $25.1 \%$ \\
\hline Solar & 6.1 & $0.9 \%$ & 0.2 & $0.1 \%$ \\
\hline Geothermal & 30.5 & $4.3 \%$ & 0.0 & $0.0 \%$ \\
\hline Small Hydro & 8.5 & $1.2 \%$ & 31.3 & $13.7 \%$ \\
\hline Total & 705.5 & $100.0 \%$ & 228.7 & $100.0 \%$ \\
\hline
\end{tabular}

While many programs use blends of renewable energy sources, more than half of all programs feature only one energy source. Among the more than 100 programs offered, 43 programs use only wind, 10 use only solar, and 9 use only biomass. The remaining programs offer a blend of two or more resources.

\footnotetext{
${ }^{9}$ New is defined as renewable resources as projects or portions of projects built specifically to serve green power customers or recently constructed projects that are used to supply green power customers and meet the regional Green-e standards for new renewables

${ }^{10}$ For details on the derivation of these estimates, see Bird and Swezey (2005).
} 


\section{Product Type}

Most utility green pricing programs are structured so that customers can purchase renewable energy to meet some or all of their electricity needs. The green power premium charged in these "energy-based" programs is typically expressed in $\varnothing / \mathrm{kWh}$ or $\$ / \mathrm{kWh}$ block. Other programs are structured to allow customers to contribute funds that support the development of renewable energy sources. These so-called "contribution programs" have become less common, and currently represent only $13 \%$ of all programs (Figure 1). Finally, a few utilities have offered programs through which customers make a monthly payment tied to the amount of renewable energy capacity that is supported ("capacity-based programs"). For example, customers might be offered the option to pay $\$ 6$ each month to support 100 watts of solar energy-generating capacity. Capacity-based programs are no longer actively marketed and, in some cases, have been phased out in favor of energy-based or contribution programs.

\section{Energy Blocks vs. Percentage of Use}

About two-thirds of energy-based programs are structured so that customers can purchase blocks of green power. Block sizes range from $15 \mathrm{kWh}$ (for energy derived exclusively from solar systems) to $1,000 \mathrm{kWh}$ (for wind energy or renewable energy blends). The most common block size offered to residential customers is $100 \mathrm{kWh}$. Many utilities offer larger block sizes to nonresidential customers, and some offer customers the option of purchasing green power for all of the electricity they use.

The remaining programs allow customers to purchase green power for some fraction of their electricity needs. Most of these programs allow residential customers to elect to have $25 \%, 50 \%$, or $100 \%$ of their electricity supplied from renewable sources, while a few offer fractions as small as $10 \%$. Often, commercial and industrial customers can purchase green power for a smaller fraction of their electricity use.

Regarding the question of whether it is better to offer a percent-of-use option or kWh-blocks, some marketers have argued that it is difficult to communicate the concept of a kWh-block to consumers, because customers do not understand $\mathrm{kWh}$ and are not used to thinking about them. Some marketers have found that this is a significant barrier to enrolling customers. They argue that consumers can more easily understand a product that is presented as a percentage of electricity use. On the other hand, selling blocks of renewable energy may provide additional flexibility to consumers to enable them to purchase smaller increments (although this could also be accomplished by offering a small percent-of-use option). Another potential benefit for customers of purchasing blocks is that the green power premium remains fixed for the customer each month and does not vary along with electricity consumption. 
A statistical analysis of green pricing data found that utilities that offer larger blocks (at least 200 $\mathrm{kWh}$ ) or higher percentages (at least $25 \%$ ) tend to have greater sales to residential customers, with no obvious impact on the overall level of customer participation (Wiser et al., 2004). In other words, customers may be willing to purchase higher quantities of renewable energy, if that is what is required to participate in the program. However, this effect may not hold for very high purchase thresholds.

\section{Pricing}

In 2004, price premiums for energy-based programs ranged from $0.33 \phi / \mathrm{kWh}$ to

$17.6 \phi / \mathrm{kWh}$, with an average premium of $2.45 \mathrm{c} / \mathrm{kWh}$ and a median of $2 \notin / \mathrm{kWh}$. Figure 2 displays price premiums for individual utility programssolar-based products dominate the high end of the price range. In 2004, the 10 utility programs with the lowest premiums for energy derived from new renewable sources had premiums ranging from $0.33 \phi / \mathrm{kWh}$ to $1 \phi / \mathrm{kWh}$, which is a lower range than in

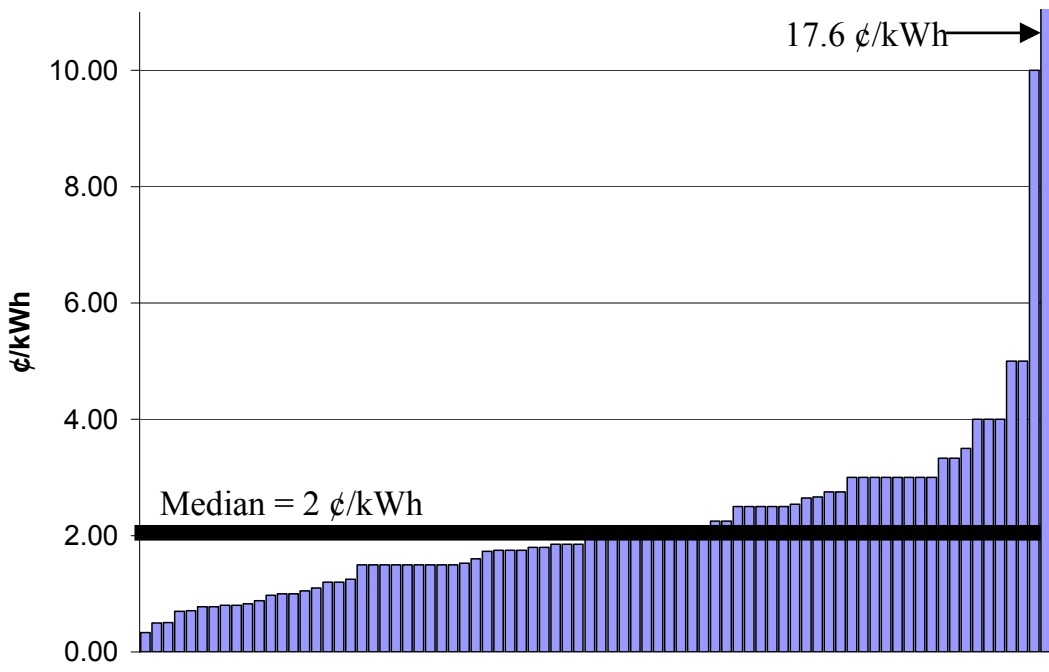

Figure 2: Utility Green Pricing Program Premiums (Energy-Based Programs Only) previous years.

In 2004, price premiums continued to decline, decreasing about $6 \%$ from 2003 . Since 2000 , the average price premium has dropped at an average annual rate of about $8 \%$. The median premium remained at $2.0 \mathrm{k} / \mathrm{kWh}$ (Table 16).

During 2004, about a dozen programs modified the price premium charged for green power, with nine reporting a premium decrease. One utility (PacifiCorp) added a premium product for nonresidential customers, which offers a lower price at higher purchase levels. Two utilities switched from a contribution program to an energy-based premium. And several other programs made minor adjustments to the structure of their premiums that had little impact on the size of the premium paid.

For those utilities that reduced their premiums, most attributed the reduction to the exemption of green power customers from fossil fuel charges or their ability to renegotiate power purchase contracts at lower rates. Other reasons that have contributed to the decline in premiums over time are the availability of state or federal financial incentives, higher than expected capacity factors, and natural gas price increases, which have reduced the cost spread between renewable energy and gas-fired generation. 
Table 16: Price Premiums of Utility Green Power Products

$(\phi / k W h)$

\begin{tabular}{|l|c|c|c|c|c|c|}
\hline & $\mathbf{1 9 9 9}$ & $\mathbf{2 0 0 0}$ & $\mathbf{2 0 0 1}$ & $\mathbf{2 0 0 2}$ & $\mathbf{2 0 0 3}$ & $\mathbf{2 0 0 4}$ \\
\hline Average Premium & 2.15 & 3.48 & 2.93 & 2.82 & 2.62 & 2.45 \\
\hline Median Premium & 2.00 & 2.50 & 2.50 & 2.50 & 2.00 & 2.00 \\
\hline Range of Premiums & $0.4-5.0$ & $(0.5)-20.0$ & $0.9-17.6$ & $0.7-17.6$ & $0.6-17.6$ & $0.33-17.6$ \\
\hline 10 Programs with Lowest Premiums* & $0.4-2.5^{* *}$ & $(0.5)-2.5$ & $1.0-1.5$ & $0.7-1.5$ & $0.6-1.3$ & $0.33-1.0$ \\
\hline
\end{tabular}

Table 17 presents green pricing premiums by utility type. IOUs have the highest average price premium at $3.14 \varnothing / \mathrm{kWh}$, while cooperatives and public utilities have lower average premiums at $2 \phi / \mathrm{kWh}$ and $2.24 \phi / \mathrm{kWh}$, respectively. Some of the differences among utility types may result from a greater tendency of IOUs to include program administration and marketing costs in the premium, or to seek recovery of program costs over a shorter period of time. The higher average premium calculated for investor-owned utilities may also stem from the fact that several IOUs offer solar-based programs with relatively high premiums, on the order of $10 \phi / \mathrm{kWh}$ or higher.

Table 17: Green Pricing Premiums by Utility Type $(\phi / k W h)$

\begin{tabular}{|l|c|c|c|c|c|c|}
\hline & \multicolumn{3}{|c|}{2003} & \multicolumn{3}{c|}{ 2004 } \\
\hline Type of Utility & Average & Median & Range & Average & Median & Range \\
\hline Investor-owned & 3.36 & 2.04 & $0.6-17.6$ & 3.14 & 2.00 & $0.3-17.6$ \\
\hline Public & 2.30 & 2.00 & $0.6-11.6$ & 2.24 & 2.00 & $0.5-11.6$ \\
\hline Cooperative & 2.34 & 2.50 & $0.9-3.5$ & 2.00 & 1.85 & $0.5-3.5$ \\
\hline All Utilities & 2.62 & 2.00 & $0.6-17.6$ & 2.45 & 2.00 & $0.3-17.6$ \\
\hline
\end{tabular}

About a half a dozen programs differentiate the premium charged for nonresidential and residential participants. Most of these programs offer lower green energy premiums to nonresidential customers, offering bulk purchase discounts for large green power purchasers. In these programs, the premium charged to nonresidential customers is generally about $0.5 \mathrm{c} / \mathrm{kWh}$ to $1.5 \phi / \mathrm{kWh}$ less than the residential green energy premium.

Because most renewable energy facilities do not rely on fuel, some utilities offer fixed-price green power products or exempt their green power customers from some fuel-cost charges. About a half-dozen utilities include this feature as a component of their green pricing product. ${ }^{11}$

\footnotetext{
${ }^{11}$ Utilities offering fuel-price stability include: Austin Energy, Edmond Electric, Eugene Water \& Electric Board, Madison Gas and Electric, OG\&E Electric, We Energies, and Xcel Energy.
} 
One of these utilities also exempts green power customers from the costs associated with making environmental improvements at some of its fossil fuel-generating facilities. Exempting customers from fossil fuel costs can be a particularly important strategy for enrolling large nonresidential customers with larger energy needs, as evidenced by the success of Austin Energy, which accounts for nearly $20 \%$ of all utility green pricing sales.

\section{Marketing}

\section{Marketing and Administration Spending}

As one might expect, spending on marketing and administration for green power programs generally varies with size of the utility; however, some large utilities spend relatively little on marketing. In 2004, 85\% of the utilities serving fewer than 100,000 customers spent less than $\$ 10,000$ annually on marketing (excluding staff time), with the remaining utilities potentially spending as much as $\$ 50,000$. Of midsized utilities ranging from 100,000 to 499,999 customers, the majority spent $\$ 10,000$ to $\$ 50,000$, with $10 \%$ spending more than $\$ 100,000$, and $25 \%$ spending less than $\$ 10,000$. Of the large utilities with more than 500,000 customers, there was a wider range of marketing expenditures reported. Thirty percent of large utilities spent less than $\$ 50,000$ on marketing, while $57 \%$ spent more than $\$ 100,000$. The top performers ${ }^{12}$ represent all of the utilities that spent more than $\$ 250,000$ on marketing and $73 \%$ of those that spent more than $\$ 100,000$. (Table 18).

Table 18: Utility Expenditures on Marketing in 2004 (excluding staff time)

\begin{tabular}{|c|c|c|c|c|c|c|}
\hline \multirow{2}{*}{$\begin{array}{r}\text { Number of Utility } \\
\text { Customers }\end{array}$} & \multicolumn{5}{|c|}{ Number of Responses } & \multirow{2}{*}{$\begin{array}{c}\text { Total } \\
\text { Responses }\end{array}$} \\
\hline & $\begin{array}{l}\text { Less than } \\
\$ 10,000\end{array}$ & $\begin{array}{l}\$ 10,000- \\
\$ 50,000\end{array}$ & $\begin{array}{l}\$ 50,000- \\
\$ 100,000\end{array}$ & $\begin{array}{l}\$ 100,000- \\
\$ 250,000\end{array}$ & $\begin{array}{l}\$ 250,000- \\
\$ 500,000\end{array}$ & \\
\hline $1-99,999$ & 33 & 6 & 0 & 0 & 0 & 39 \\
\hline $100,000-499,999$ & 5 & 12 & 1 & 2 & 0 & 20 \\
\hline $500,000-999,999$ & 0 & 3 & 2 & 4 & 2 & 11 \\
\hline $1,000,000+$ & 2 & 2 & 1 & 5 & 2 & 12 \\
\hline Total Respondents & 40 & 23 & 4 & 11 & 4 & 82 \\
\hline $\begin{array}{r}\text { Top Performers/ } \\
\% \text { All Respondents }\end{array}$ & $6 / 15 \%$ & $4 / 17 \%$ & $1 / 25 \%$ & $8 / 73 \%$ & $4 / 100 \%$ & $23 / 28 \%$ \\
\hline
\end{tabular}

With respect to program-administration spending, the data reflect the same general trends as with marketing expenditures (Table 19). Of the small utilities serving fewer than 100,000 customers, about $85 \%$ spent less than $\$ 10,000$ on administration (including staff time), with the remainder spending up to $\$ 50,000$. Of the midsized utilities ranging from 100,000 to 499,999 customers, most spent $\$ 10,000$ to $\$ 50,000$ on program administration, with $10 \%$ spending more than $\$ 100,000$. The largest utilities serving more than 500,000 customers reported a wide range of expenditures on administration, similar to the marketing data. Half of the large utilities spent more than $\$ 100,000$ on administration, while 39\% spent less than $\$ 50,000$.

\footnotetext{
${ }^{12}$ The top performers are defined as those that were among the top 10 programs for customer participants, green power sales, and customer participation rate, according to the NREL rankings (see Appendix C).
} 
The top performers represented $64 \%$ of the utilities that spent more than $\$ 100,000$ on program administration and $67 \%$ of those that spent more than $\$ 250,000$. However, the top performers represent a higher fraction of the utilities that spent between $\$ 10,000$ and $\$ 100,000$, compared to data on marketing expenditures. Therefore, a number of the top performers reported spending less on administration than marketing.

Table 19: Utility Expenditures on Program Administration in 2004 (including staff time)

\begin{tabular}{|c|c|c|c|c|c|c|}
\hline \multirow{2}{*}{$\begin{array}{l}\text { Number of Utility } \\
\text { Customers }\end{array}$} & \multicolumn{5}{|c|}{ Number of Responses } & \multirow{2}{*}{$\begin{array}{c}\text { Total } \\
\text { Responses }\end{array}$} \\
\hline & $\begin{array}{l}\text { Less than } \\
\$ 10,000\end{array}$ & $\begin{array}{l}\$ 10,000- \\
\$ 50,000\end{array}$ & $\begin{array}{l}\$ 50,000- \\
\$ 100,000 \\
\end{array}$ & $\begin{array}{l}\$ 100,000- \\
\$ 250,000\end{array}$ & $\begin{array}{l}\$ 250,000- \\
\$ 500,000\end{array}$ & \\
\hline $1-99,999$ & 32 & 5 & 0 & 0 & 0 & 37 \\
\hline $100,000-499,999$ & 4 & 11 & 2 & 1 & 1 & 19 \\
\hline $500,000-999,999$ & 1 & 4 & 1 & 4 & 1 & 11 \\
\hline $1,000,000+$ & 2 & 2 & 2 & 6 & 1 & 13 \\
\hline $\begin{array}{r}\text { Total } \\
\text { Respondents }\end{array}$ & 39 & 22 & 5 & 11 & 3 & 80 \\
\hline $\begin{array}{r}\text { Top Performers/ } \\
\% \text { Total } \\
\text { Respondents }\end{array}$ & $5 / 13 \%$ & $6 / 27 \%$ & $3 / 60 \%$ & $7 / 64 \%$ & $2 / 67 \%$ & $23 / 29 \%$ \\
\hline
\end{tabular}

In 2004, utilities reported that a median of $8.5 \%$ (average of $20 \%$ ) of the total green power premium was spent on marketing and program administration (Table 20), ${ }^{13}$ while the topperforming programs reported spending a median of $25 \%$ and an average of $28 \%$. Compared to data for 2003, utilities appear to be spending slightly more of the premium on marketing and administration.

Table 20: Marketing and Administrative Expenditures as Percentage of Premium (2004)

\begin{tabular}{|c|c|c|c|c|c|}
\hline \multicolumn{2}{|c|}{ Average } & \multicolumn{2}{c|}{ Median } & \multicolumn{2}{c|}{ Responses } \\
\hline $\mathbf{2 0 0 3}$ & $\mathbf{2 0 0 4}$ & $\mathbf{2 0 0 3}$ & $\mathbf{2 0 0 4}$ & $\mathbf{2 0 0 3}$ & $\mathbf{2 0 0 4}$ \\
\hline $16.6 \%$ & $20.0 \%$ & $5.0 \%$ & $8.5 \%$ & 36 & 60 \\
\hline
\end{tabular}

\footnotetext{
${ }^{13}$ In 2002, utilities reported spending median of $15 \%$ (average of 20\%) of their program budgets on marketing. It is not possible to compare responses for 2002 and 2003/2004, because the questions differed.
} 
Thirty programs (38\%) indicated that program participants cover all costs associated with the green pricing program. Of the remaining $62 \%$ of programs in which nonparticipants cover some costs, most program managers explained that some marketing and administrative costs were not attributed to the program (i.e., spread among all ratepayers). The other most commonly cited reasons were that the green pricing program received grants or other contributions, and that the utility spread the cost of unsold renewable energy among all ratepayers (Table 21). Results were similar in 2003.

Table 21: Explanation of Costs Born by Nonparticipants

\begin{tabular}{|l|c|}
\hline & $\begin{array}{c}\text { Number of } \\
\text { Responses }\end{array}$ \\
\hline $\begin{array}{l}\text { Some marketing and administrative costs shared by all ratepayers (or } \\
\text { not attributed to the green pricing program) }\end{array}$ & 29 \\
\hline $\begin{array}{l}\text { The program receives grants, public goods funds, subsidies, or other } \\
\text { contributions }\end{array}$ & 4 \\
\hline $\begin{array}{l}\text { The utility spreads the cost of unsold renewable energy among all } \\
\text { ratepayers }\end{array}$ & 3 \\
\hline $\begin{array}{l}78 \text { programs responded, and } 47 \text { programs provided explanations, not all explanations are accounted for in } \\
\text { this table. }\end{array}$ & \\
\hline
\end{tabular}

\section{Customer Acquisition}

One measure of the cost of marketing a green pricing program is customer-acquisition cost - the marketing expenditures divided by the number of new customers that enroll in the program. For 2004, utilities providing data reported median and average residential customer-acquisition costs for green pricing programs of $\$ 30$ and $\$ 42$, respectively (Table 22). ${ }^{14}$ However, the responses varied widely, ranging from $\$ 0$ to $\$ 285$ (Figure 3). The top-performing programs reported median and average residential customer-acquisition costs of $\$ 40$ and $\$ 48$, respectively.

Table 22: Residential Customer-Acquisition Costs by Year

\begin{tabular}{|l|c|c|c|c|}
\hline & $\mathbf{2 0 0 2}$ & $\mathbf{2 0 0 3}$ & $\mathbf{2 0 0 4}$ & $\begin{array}{c}\text { 2004 Top } \\
\text { Performers }\end{array}$ \\
\hline Average & $\$ 44$ & $\$ 36$ & $\$ 42$ & $\$ 48$ \\
\hline Median & $\$ 30$ & $\$ 31$ & $\$ 30$ & $\$ 40$ \\
\hline No.of Respondents & 25 & 22 & 43 & 18 \\
\hline
\end{tabular}

\footnotetext{
${ }^{14}$ Only about half of the utilities provided this information. The relative lack of responses may be resultant of some utilities not tracking customer-acquisition costs.
} 
Table 23: Residential Customer-Acquisition Costs by Utility Size

\begin{tabular}{|r|c|c|c|c|c|c|}
\hline Type of Utility & $\begin{array}{c}\mathbf{2 0 0 3} \\
\text { Average }\end{array}$ & $\begin{array}{c}\mathbf{2 0 0 3} \\
\text { Median }\end{array}$ & $\begin{array}{c}\mathbf{2 0 0 3} \\
\text { Responses }\end{array}$ & $\begin{array}{c}\mathbf{2 0 0 4} \\
\text { Average }\end{array}$ & $\begin{array}{c}\mathbf{2 0 0 4} \\
\text { Median }\end{array}$ & $\begin{array}{c}\mathbf{2 0 0 4} \\
\text { Responses }\end{array}$ \\
\hline $1-99,999$ Customers & $\$ 10$ & $\$ 5$ & 7 & $\$ 12$ & $\$ 4$ & 12 \\
\hline $\begin{array}{r}100,000-499,999 \\
\text { Customers }\end{array}$ & $\$ 46$ & $\$ 40$ & 7 & $\$ 56$ & $\$ 35$ & 13 \\
\hline $\begin{array}{r}500,000-999,999 \\
\text { Customers }\end{array}$ & $\$ 44$ & $\$ 38$ & 4 & $\$ 60$ & $\$ 55$ & 9 \\
\hline $\begin{array}{r}1,000,000 \\
\text { Customers }\end{array}$ & $\$ 57$ & $\$ 46$ & 4 & $\$ 41$ & $\$ 36$ & 9 \\
\hline All Utilities & $\$ 36$ & $\$ 31$ & $\mathbf{2 2}$ & $\mathbf{\$ 4 2}$ & $\$ 30$ & $\mathbf{4 3}$ \\
\hline
\end{tabular}

Customer-acquisition costs differed considerably depending on the size of the utility (Table 23), with utilities serving more than 100,000 customers reporting higher customer-acquisition costs than smaller utilities. Some of the variability may be due to the types of costs that the utilities included in the calculation. For example, some utilities do not attribute all of the costs of marketing and administration to the program, which would lead to lower per-customer costs. Also, large utilities may have the resources to track expenditures more closely.

\section{Marketing Techniques Employed}

The 2004 questionnaire asked respondents to indicate the various marketing techniques applied to their green pricing programs (Table 24). As in previous years, advertising programs through utility newsletters, bill inserts, and news articles (publicity) were among the top marketing strategies used. ${ }^{15,16}$ Events and Web marketing also ranked highly in 2004. Other

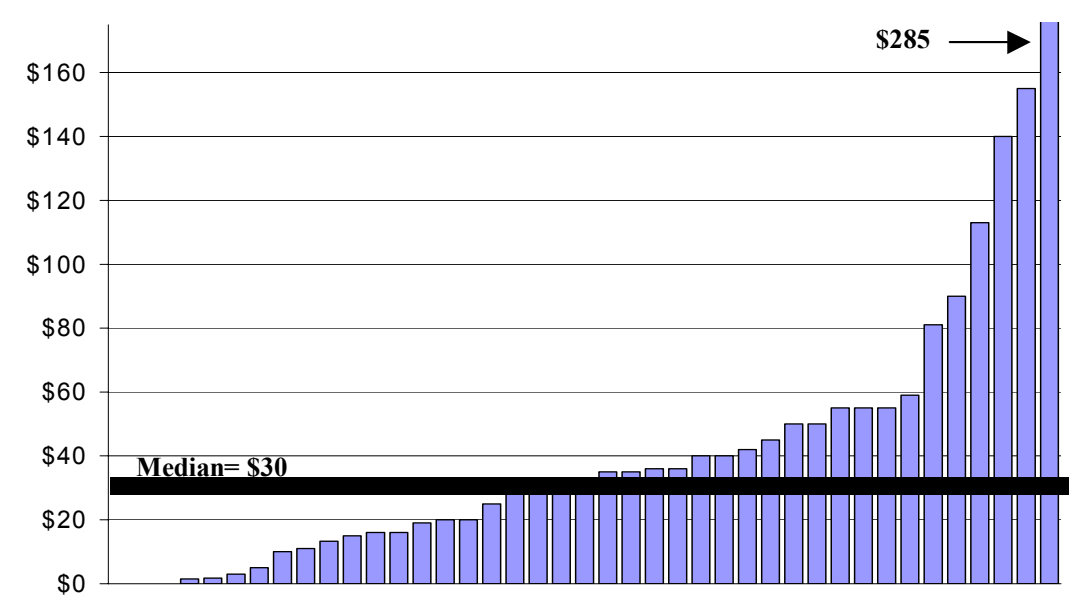

Figure 3: Utility Customer-Acquisition Costs (2004) marketing strategies reported by utilities - but not listed in the questionnaire - were door-to-door sales campaigns (reported by three utilities), bangtails (detachable order forms on payment envelopes) (3), and print advertisements in publications other than newspapers and magazines (2).

\footnotetext{
${ }^{15}$ In 2003, the "events" category was not listed as a specific option in the survey, but was listed under the "other" category by some respondents. The 2002 and 2004 surveys both included "events" as a category, and can therefore be compared with each other.

${ }^{16}$ Lieberman (2002) reviewed marketing data for public utilities with similar findings, except that direct mail was ranked higher.
} 
In 2004, utilities were also asked to rank the effectiveness of the various marketing techniques listed in the questionnaire. Other (which included door-to-door sales, bangtails, and print ads) received the highest ranking of 3.9 out of a possible 5, followed by direct mail (3.7), and direct sales (3.5). Publicity and Web marketing also received fairly high effectiveness scores of 3.4 and 3.3, respectively. Interestingly, the techniques with the highest effectiveness ranking were not necessarily the most commonly used. For example, direct mail and direct sales were among the top three most effective techniques, but were only implemented by $35 \%$ and $38 \%$ of respondents, respectively. Further, billboards, kiosks, and telemarketing all received effectiveness rankings above 3 , but were implemented by fewer than $10 \%$ of utilities. In 2004, programs employed an average of four of the marketing strategies listed in the questionnaire, while the top performers reported an average of seven. About one-quarter of utilities reported using three or fewer marketing techniques (Table 25).

Table 24: Marketing Techniques Used by Utilities

\begin{tabular}{|c|c|c|c|c|c|c|c|}
\hline & \multicolumn{3}{|c|}{$\begin{array}{c}\text { Percent of Utilities Using } \\
\text { Technique }\end{array}$} & \multicolumn{2}{|c|}{$\begin{array}{c}\text { Percent Top } \\
\text { Performers Using } \\
\text { Technique** }\end{array}$} & \multicolumn{2}{|c|}{$\begin{array}{c}\text { Average } \\
\text { Usefulness Rank } \\
\text { (2004 only)^ }\end{array}$} \\
\hline & 2002 & 2003 & 2004 & 2003 & 2004 & All & $\begin{array}{c}\text { Top } \\
\text { Performers }\end{array}$ \\
\hline Utility newsletter & $70 \%$ & $81 \%$ & $78 \%$ & $87 \%$ & $73 \%$ & 2.9 & 2.9 \\
\hline Events & $80 \%$ & $24 \%{ }^{*}$ & $74 \%$ & $40 \% *$ & $73 \%$ & 2.6 & 2.7 \\
\hline Bill inserts & $61 \%$ & $83 \%$ & $74 \%$ & $87 \%$ & $73 \%$ & 3.2 & 3.4 \\
\hline Publicity & $63 \%$ & $64 \%$ & $56 \%$ & $67 \%$ & $69 \%$ & 3.4 & 3.1 \\
\hline Web Marketing^ & $\mathrm{n} / \mathrm{a}$ & $\mathrm{n} / \mathrm{a}$ & $56 \%$ & $\mathrm{n} / \mathrm{a}$ & $73 \%$ & 3.3 & 3.4 \\
\hline Direct Sales^ & $\mathrm{n} / \mathrm{a}$ & $\mathrm{n} / \mathrm{a}$ & $38 \%$ & $\mathrm{n} / \mathrm{a}$ & $50 \%$ & 3.5 & 3.8 \\
\hline Newspaper ads & $43 \%$ & $53 \%$ & $36 \%$ & $60 \%$ & $46 \%$ & 2.5 & 2.1 \\
\hline Direct mail & $55 \%$ & $48 \%$ & $35 \%$ & $67 \%$ & $62 \%$ & 3.7 & 3.7 \\
\hline $\begin{array}{l}\text { Partner with } \\
\text { Environmental } \\
\text { Organizations }^{\wedge \wedge}\end{array}$ & $\mathrm{n} / \mathrm{a}$ & $\mathrm{n} / \mathrm{a}$ & $26 \%$ & $\mathrm{n} / \mathrm{a}$ & $54 \%$ & 2.7 & 2.8 \\
\hline Radio ads & $37 \%$ & $45 \%$ & $22 \%$ & $53 \%$ & $19 \%$ & 2.5 & 1.2 \\
\hline Other & $32 \%$ & $41 \%$ & $19 \%$ & $60 \%$ & $46 \%$ & 3.9 & 4.1 \\
\hline Television ads & $20 \%$ & $22 \%$ & $15 \%$ & $13 \%$ & $31 \%$ & 2.3 & 1.8 \\
\hline Retail Partners^ & $\mathrm{n} / \mathrm{a}$ & $\mathrm{n} / \mathrm{a}$ & $11 \%$ & $\mathrm{n} / \mathrm{a}$ & $23 \%$ & 2.9 & 3.0 \\
\hline Billboards & $7 \%$ & $7 \%$ & $8 \%$ & $7 \%$ & $12 \%$ & 3.2 & 2.0 \\
\hline $\begin{array}{l}\text { Community } \\
\text { Challenges^ }\end{array}$ & $\mathrm{n} / \mathrm{a}$ & $\mathrm{n} / \mathrm{a}$ & $7 \%$ & $\mathrm{n} / \mathrm{a}$ & $19 \%$ & 2.5 & 2.4 \\
\hline Kiosks $^{\wedge}$ & $\mathrm{n} / \mathrm{a}$ & $\mathrm{n} / \mathrm{a}$ & $7 \%$ & $\mathrm{n} / \mathrm{a}$ & $4 \%$ & 3.2 & 2.0 \\
\hline Telemarketing & $8 \%$ & $14 \%$ & $6 \%$ & $20 \%$ & $12 \%$ & 3.2 & 4.3 \\
\hline $\begin{array}{l}\text { *Note: "Events" was li } \\
\text { in under "Other." } \\
\text { **Top performers are } \\
\text { programs responded } \\
\text { ^ } \mathrm{Ranking} \text { system is } 1 \\
\wedge \wedge \text { New category in } 20 \\
60 \text { programs provided }\end{array}$ & $\begin{array}{l}\text { is a spe } \\
\text { d as ut } \\
\text { questi } \\
\text { h } 5 \text { beir }\end{array}$ & $\begin{array}{l}\text { tion in the } \\
\text { lat make } \\
\text { nost usefi }\end{array}$ & $\begin{array}{l}\text { and } 20 \\
p 10 \text { lis } \\
\text { keting } t\end{array}$ & $\begin{array}{l}\text { tionnaire } \\
\text { rticipants } \\
\text { e. Rankin }\end{array}$ & $\begin{array}{l}2003 \mathrm{re} \\
\text { partici } \\
\text { only in }\end{array}$ & 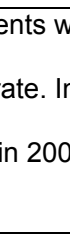 & $\begin{array}{l}\text { able to write it } \\
4,26 \text { top }\end{array}$ \\
\hline
\end{tabular}


Compared to all programs, the top performers more commonly use techniques such as Web marketing, direct mail, direct sales, publicity, partnerships with environmental organizations, television ads, retail partnerships, community challenges, and telemarketing. One potential reason for differences in marketing strategies used by top performers may be related to the marketing budgets. The top performers represent a significant majority of the programs that spend the most on marketing (see Table 18).

Table 25: Number of Marketing Techniques Used by Utilities (2004)

\begin{tabular}{|c|c|c|}
\hline $\begin{array}{c}\text { Number of Techniques } \\
\text { Used by Utilities }\end{array}$ & $\mathbf{2 0 0 3}$ & $\mathbf{2 0 0 4}$ \\
\hline $0-1$ & $7 \%$ & $6 \%$ \\
\hline $2-3$ & $26 \%$ & $20 \%$ \\
\hline $4-6$ & $45 \%$ & $34 \%$ \\
\hline $7-9$ & $21 \%$ & $22 \%$ \\
\hline $10-12$ & n/a & $18 \%$ \\
\hline \multicolumn{2}{|c|}{$\begin{array}{c}\text { Note: There were 58 responses to this question in 2003 and } 88 \text { in } \\
\text { 2004. Percentages may not add to 100\% due to rounding. }\end{array}$} \\
\hline
\end{tabular}

\section{Program Implementation}

\section{Enrollment Options}

Utilities reported that the most common methods for enrolling customers in green pricing programs included phoning through the utility's call center, returning mail-in cards, using the utility's Web site, and signing up during special events (Table 26). Web site enrollment options have become more common since 2002, perhaps because utilities have improved their Web sites or increased their Web presence.

Table 26: Methods of Enrolling in Green Pricing Programs

\begin{tabular}{|l|c|c|c|c|c|}
\hline & $\begin{array}{c}\mathbf{2 0 0 2} \\
\text { \% Using } \\
\text { Method }\end{array}$ & $\begin{array}{c}\mathbf{2 0 0 3} \\
\text { \% Using } \\
\text { Method }\end{array}$ & $\begin{array}{c}\mathbf{2 0 0 4} \\
\text { \% Using } \\
\text { Method }\end{array}$ & $\begin{array}{c}\text { Top } \\
\text { Performers } \\
\text { \% Using } \\
\text { Method }\end{array}$ & $\begin{array}{c}\text { Rank } \\
\text { 1 to 5, 5=highest }\end{array}$ \\
\hline $\begin{array}{l}\text { Phone (utility } \\
\text { call center) }\end{array}$ & $92 \%$ & $87 \%$ & $84 \%$ & $89 \%$ & 2.7 \\
\hline $\begin{array}{l}\text { Returning } \\
\text { mail-in card }\end{array}$ & $90 \%$ & $85 \%$ & $83 \%$ & $89 \%$ & 3.3 \\
\hline Utility Web site & $74 \%$ & $83 \%$ & $80 \%$ & $85 \%$ & 2.6 \\
\hline $\begin{array}{l}\text { Enroll at } \\
\text { special events }\end{array}$ & $90 \%$ & $85 \%$ & $73 \%$ & $73 \%$ & 2.8 \\
\hline Other & $23 \%$ & $31 \%$ & $48 \%$ & $65 \%$ & 3.6 \\
\hline $\begin{array}{l}\text { Check-box on } \\
\text { utility bill }\end{array}$ & $8 \%$ & $12 \%$ & $15 \%$ & $23 \%$ & 3.4 \\
\hline \multicolumn{7}{|l|}{ Note: The number of respondents was 62 in 2002, 59 in 2003, and 88 in 2004. } \\
\hline
\end{tabular}


Only about $15 \%$ of utilities allowed customers to enroll by checking a box on their utility bills, but those that did ranked it high in effectiveness. Other methods that were ranked as relatively effective with scores greater than 3 out of 5 included "other" methods (which respondents were asked to list) and mail-in cards. Some of the enrollment options listed under "other" included bill inserts (reported by 12 utilities), direct sales through account representatives, both residential and commercial (10), and phone marketing by a contractor (5), bangtails (3), and enrolling customers through retail partners or at the utility itself (2). On average, utilities offered three of the six enrollment options listed in the questionnaire. The top-performing programs were more likely to use most of the techniques listed, particularly a check-box on the utility bill and other enrollment methods.

\section{Enrollment Term}

Roughly one-third of utilities require residential and nonresidential customers to subscribe to green pricing programs for a minimum period of time (Table 27). One year is the most common minimum enrollment period, with requirements ranging from 2 months to 5 years for residential customers and 2 months to 10 years for nonresidential customers. In some cases, utilities require nonresidential customers to enroll for longer periods of time than residential customers. In 2004, only four residential and six non-residential programs had enrollment terms of more than one year in length.

Table 27: Enrollment Term by Customer Segment

\begin{tabular}{|l|c|c|}
\hline & Residential & Nonresidential \\
\hline Percent of utilities with a minimum enrollment term & $30 \%$ & $37 \%$ \\
\hline Most common enrollment term & 1 year & 1 year \\
\hline Range of enrollment requirements & $\begin{array}{c}2 \text { months to } 5 \\
\text { years }\end{array}$ & $\begin{array}{c}2 \text { months to } 10 \\
\text { years }\end{array}$ \\
\hline *Of 78 programs that responded to this question. \\
\hline
\end{tabular}

\section{Program Evaluations and Market Research}

Fifty-eight of the 91 (64\%) utilities responding reported that they had conducted customer research to aid the design of their green pricing program or to develop a marketing plan. Of the 58 utilities, 29 did so in 2004 and 22 did so in multiple years. The types of research ranged from consumer surveys conducted by phone, mail, or the Web (28 utilities reported), focus groups (13), customer profiling and demographics (7), research to test the effectiveness of marketing messages or strategies (4), and research to determine customer awareness (3), customer satisfaction (1), and to evaluate product design (1). Of the top-performing programs, $81 \%$ reported conducting market research, compared to $64 \%$ of programs overall. 
In terms of program evaluation, 41 respondents (46\%) indicated that they had performed a program evaluation in 2004 or earlier. Fourteen of the programs reported evaluating their programs annually or biannually. Utilities reported evaluating marketing efforts (messaging, market channel effectiveness, advertising effectiveness, campaign effectiveness, and acquisition costs) (14), product pricing, block size or contract terms (11), program participation or success in meeting program goals (7), all aspects of the program (5), customer awareness (4), customer satisfaction (3), customer profiling and demographics (2), program costs (2), program supply mix (1), and customer recognition (1). Of the top-performing programs, $65 \%$ reported conducting one or more program evaluation, compared to $46 \%$ of all programs.

\section{Customer Value}

Response to utility green pricing programs can be influenced by additional values offered to both residential and nonresidential customers (Wiser et al. 2004). For example, customers may be more willing to participate in a program if their participation is recognized or rewarded, or if they receive other products and services, such as compact fluorescent light bulbs or store discounts.

Table 28 indicates the percentage of utilities that provide additional benefits to customers, based on a list of options included in the 2002-2004 questionnaires. Of the 11 options listed, respondents indicated that their utilities offered an average of two additional benefits to their green pricing customers. As in previous years, the most common added benefits in 2004 were 1) to inform customers about the status of the program through newsletters that provide periodic program updates, 2) to recognize participants with plaques or other items, 3) to provide decals that can be displayed in windows, and 4) to recognize business customers through ads in local media. The fraction of utilities offering 1) tours to renewable energy facilities and 2) installing renewable energy systems on schools or offering renewable energy education programs have trended downward during the past couple of years. A relatively small fraction of utilities offer compact fluorescent light bulbs or energy efficiency products, discounts or promotions at local businesses, protection from fuel cost increases, or exemption from environmental fees (e.g., fees designated for installing emission control equipment at fossil fuel plants).

As in 2003, the top-performing programs were more likely to offer many of the benefits listed in Table 28, with the exception of tours and installations on schools or educational programs. For example, $65 \%$ of the top performers recognized business participants through ads in local media or recognized participants with plaques or other items, compared to about $50 \%$ of all programs. The top performers were also more likely to provide decals for display in store windows, discounts or promotions at local businesses, to protect customers from fuel cost increases, and provide energy efficiency products. Overall, top performers reported providing an average of 4.1 of the benefits listed, compared to an average of 2 for all programs. 
Table 28: Methods of Providing Additional Program Benefits

\begin{tabular}{|c|c|c|c|c|}
\hline & $\begin{array}{l}2002 \\
\% \text { Using } \\
\text { Method } \\
\end{array}$ & $\begin{array}{l}2003 \\
\% \text { Using } \\
\text { Method }\end{array}$ & $\begin{array}{l}2004 \\
\% \text { Using } \\
\text { Method }\end{array}$ & $\begin{array}{c}\text { Top Performers } \\
2004 \% \text { Using } \\
\text { Method }^{*} \\
\end{array}$ \\
\hline $\begin{array}{l}\text { Newsletters that provide } \\
\text { program updates }\end{array}$ & $62 \%$ & $64 \%$ & $61 \%$ & $69 \%$ \\
\hline $\begin{array}{l}\text { Plaques or other items for } \\
\text { recognition }\end{array}$ & $40 \%$ & $49 \%$ & $51 \%$ & $65 \%$ \\
\hline $\begin{array}{l}\text { Decals for display in store } \\
\text { windows }\end{array}$ & $59 \%$ & $56 \%$ & $49 \%$ & $73 \%$ \\
\hline $\begin{array}{l}\text { Recognition of business } \\
\text { customers in program ads or } \\
\text { local media }\end{array}$ & $44 \%$ & $51 \%$ & $49 \%$ & $65 \%$ \\
\hline $\begin{array}{l}\text { Tours to renewable energy } \\
\text { project sites }\end{array}$ & $35 \%$ & $29 \%$ & $23 \%$ & $19 \%$ \\
\hline $\begin{array}{l}\text { Installations on } \\
\text { schools/renewable energy } \\
\text { education programs }\end{array}$ & $30 \%$ & $25 \%$ & $19 \%$ & $15 \%$ \\
\hline Other & $5 \%$ & $12 \%$ & $16 \%$ & $19 \%$ \\
\hline $\begin{array}{l}\text { Compact fluorescents or } \\
\text { efficiency products }\end{array}$ & $22 \%$ & $12 \%$ & $15 \%$ & $23 \%$ \\
\hline $\begin{array}{l}\text { Discounts or promotions at } \\
\text { local businesses }\end{array}$ & $8 \%$ & $12 \%$ & $12 \%$ & $35 \%$ \\
\hline $\begin{array}{l}\text { Protection from fuel-cost } \\
\text { increases }\end{array}$ & $11 \%$ & $10 \%$ & $9 \%$ & $23 \%$ \\
\hline $\begin{array}{l}\text { Exemption from } \\
\text { environmental fees }\end{array}$ & $2 \%$ & $2 \%$ & $1 \%$ & $4 \%$ \\
\hline
\end{tabular}

\section{Conclusions and Observations}

At the end of 2004, nearly 600 utilities -including many small municipal and cooperative utilities - offered green pricing programs to nearly 40 million customers in 34 states. Nearly 20\% of all utilities nationwide now offer a green pricing option

Consumer response to utility green pricing programs continued its strong growth, as evidenced by utility green power sales. Sales increased by $43 \%$ to nearly 2 billion $\mathrm{kWh}$ in 2004 , following annual growth of $44 \%$ in 2003, and 56\% in 2002. The sales increase in 2004 resulted from both an increase in customer participants as well as larger purchases by nonresidential customers. However, green pricing sales still represent a very small fraction of total utility electricity sales, with an average considerably below $1 \%$-although some utilities have achieved sales penetration rates of as much as $3 \%$. 
The number of customers participating in utility green pricing programs also increased in 2004, but at a slower pace than sales. At the end of 2004, more than 330,000 customers participated in utility green pricing programs, a $25 \%$ increase from $2003 .{ }^{17}$ For the first time in several years, the number of residential and nonresidential participants increased at the same rate; whereas, in previous years, nonresidential customers grew faster. In 2003, for example, the number of nonresidential participants grew by $66 \%$, compared to $15 \%$ growth in the residential sector. The comparable growth rates among customer sectors in 2004 may suggest greater competition for commercial customers from REC marketers, or a renewed emphasis on marketing to residential customers. Customer attrition rates also increased in 2004 to an average of about $10 \%$, suggesting that utilities may need to place greater emphasis on customer retention.

While a relatively small number of green pricing programs continue to dominate participation and sales figures, growth is occurring in a greater number of utility programs. Whereas, the top 10 programs accounted for $85 \%$ of green energy sales in 2003 , the share dropped to about $70 \%$ in 2004. Similarly, the fraction of customer participants attributed to the top 10 programs decreased from $74 \%$ in 2003 to $63 \%$ in 2004. As in the past, one utility program (Austin Energy) accounted for nearly $20 \%$ of all green pricing sales. This utility offers a fixed-price product that protects participating customers from nonrenewable fuel-cost increases for up to 10 years. This value-added strategy has proven to be extremely popular among nonresidential customers and, if replicated, could increase industry sales dramatically.

Average participation rates in green pricing programs have remained relatively steady at $1.3 \%$. However, the 10 most successful programs have achieved participation rates of between $4 \%$ and $15 \%$, with most clustered from $4 \%$ to $6 \%$. This suggests that higher rates are possible with dedicated marketing and outreach campaigns, or in programs that offer superior value propositions. However, these rates remain well below the $50 \%$ to $70 \%$ of customers who indicate they are willing to pay a premium for green power in market research surveys (Farhar, 1999).

The price premiums charged for green power continued on a downward trend. The average premium has fallen from $2.93 \phi / \mathrm{kWh}$ in 2001 to $2.45 \phi / \mathrm{kWh}$ in 2004 ; the median premium was $2 \not / \mathrm{kWh}$ in 2004. A number of programs were able to reduce the price premium in 2004 because of fossil fuel-charge exemptions or by renegotiating power purchase contracts at lower rates. Although a couple of utilities introduced programs that offer lower premiums for large, nonresidential purchasers, still only a handful of utilities offer such options. This may partly explain the slower growth in the number of nonresidential customers as utilities are facing increasing competition for nonresidential sales from REC marketers.

Utilities reported a median cost of acquiring new residential customers of $\$ 30$, consistent with data reported in previous years. Marketing expenditures generally vary with utility size, but there is wide variation in expenditures among the largest utilities. On average, the top-performing programs spend a greater portion of program revenues on marketing and represent most of the top marketing spenders. Thus, the level of marketing expenditures appears to be important to program success.

\footnotetext{
${ }^{17}$ If utility programs offered in restructured electricity markets are included, the total number of customer participants is 361,000 .
} 
The top performers generally use a larger number of marketing techniques than other utilities. Utilities ranked the following marketing techniques as among the most effective: direct mail, direct sales, publicity, Web marketing, and other techniques (e.g., door-to-door sales, bangtails, print ads). However, these and other techniques that received high effectiveness scores are not necessarily the most commonly used. In general, utilities may benefit from diversifying their marketing activities to include some of the more effective strategies.

At the end of 2004, about $700 \mathrm{MW}$ of new renewable energy capacity was serving customers participating in utility green pricing programs, with another $225 \mathrm{MW}$ planned. Thus, green pricing continues to be a viable strategy for supporting the development of new renewable energy sources. Nevertheless, current success can be attributed to a relatively small number of programs. Continued industry growth will depend largely on whether consumer access to green pricing spreads beyond the one-fifth of utilities that currently offer programs and whether the success of the top-performing programs can be duplicated by other utilities. Additional challenges include retaining existing program participants as well as attracting new nonresidential customers, particularly in light of increased competition from REC marketers. 


\section{References}

Bird, L. and K. Cardinal, 2004. Trends in Utility Green Pricing Programs (2003). Golden, CO: National Renewable Energy Laboratory. September.

Bird, L. and B. Swezey, 2005. Estimates of New Renewable Energy Capacity Serving U.S. Green Power Markets (2004). Golden, CO: National Renewable Energy Laboratory, May. http://www.eere.energy.gov/greenpower/resources/tables/new_gp_cap.shtml

Bird, L. and B. Swezey, 2004. Green Power Marketing in the United States: A Status Report (Seventh Edition), NREL/TP-620-36823. Golden, CO: National Renewable Energy Laboratory, September. http://www.eere.energy.gov/greenpower/pdfs/36823.pdf

Bird, L., B. Swezey, and J. Aabakken, 2004. Utility Green Pricing Programs: Design, Implementation, and Consumer Response. Report prepared by National Renewable Energy Laboratory, Golden Colorado, February. NREL/TP-620-35618.

http://www.eere.energy.gov/greenpower/resources/pdfs/nrel 35618.pdf

Farhar, B., 1999. Willingness to Pay for Electricity from Renewable Resources: A Review of Utility Market Research, NREL/TP-550-26148. Golden, CO: National Renewable Energy Laboratory, July. http://www.eere.energy.gov/greenpower/farhar_26148.html

Holt, E.A., and M. Holt, 2004. Green Pricing Resource Guide (2nd Edition), Ed Holt \& Associates, Inc., Harpswell, Maine. Prepared for the American Wind Energy Association, Washington DC, September.

http://www.awea.org/greenpower/greenPricingResourceGuide040726.pdf

Lieberman, D., 2002. Green Pricing at Public Utilities: A How-To Guide Based on Lessons Learned to Date, Prepared for the Public Renewables Partnership by the Center for Resource Solutions, San Francisco, California, October.

Swezey, B. and L. Bird, 2001. Utility Green Pricing Programs: What Defines Success? NREL/TP-620-29831. Golden, CO: National Renewable Energy Laboratory, August. http://www.eere.energy.gov/greenpower/29831.pdf

Swezey, B. and L. Bird, 2000. Green Power Marketing in the United States: A Status Report (Fifth Edition), NREL/TP-620-28738. Golden, CO: National Renewable Energy Laboratory, August. http://www.eere.energy.gov/greenpower/pdf/28738.pdf

Swezey, B. and L. Bird, 1999. Information Brief on Green Power Marketing (Fourth Edition), NREL/TP-620-26901. Golden, CO: National Renewable Energy Laboratory, August. http://www.nrel.gov/analysis/emaa/brief 4.html

Washington Department of Community, Trade and Economic Development (CTED) and Utilities Transportation Commission (UTC), 2002. Green Power Programs in Washington: A 
Report to the Legislature. Olympia, WA, December.

http://www.cted.wa.gov/DesktopDefault.aspx?tabid=440

Washington Department of Community, Trade and Economic Development (CTED) and Utilities Transportation Commission (UTC), 2003. Green Power Programs in Washington: A Report to the Legislature. Olympia, WA, December.

http://www.cted.wa.gov/uploads/Green\%20Power\%2011-24-03.doc

Washington Department of Community, Trade and Economic Development (CTED) and Utilities Transportation Commission (UTC), 2004. Green Power Programs in Washington: A Report to the Legislature. Olympia, WA, December.

Wiser, R., S. Olson, L. Bird and B. Swezey, 2004. Utility Green Pricing Programs: A Statistical Analysis of Program Effectiveness, LBNL-54437. Berkeley, CA: Lawrence Berkeley National Laboratory, February. http://www.eere.energy.gov/greenpower/resources/pdfs/lbnl_54437.pdf 


\section{Appendix A}

\section{Utility Green Power Program Questionnaire}

Confidentiality - Individual utility responses to this survey regarding customers, sales, and marketing information will be held confidential. Data are used to prepare NREL's list of top ten utility green power programs and to provide aggregate industry data to the U.S. DOE and the general public.

1. Utility name

2. Name of respondent (phone/email)

3. Name of green power program

(if you have multiple programs, please fill out a separate form for each program)

4. Is the program marketed in partnership with a third-party? If so, please name

5. Year program was launched

6. In which states is the program offered?

7. Data reported should be for 2004. If data are provided for a different 12-month period, please specify.

\section{Participation}

8. In the table below, please provide participation data as of December 31, 2004.

\begin{tabular}{|l|l|}
\hline Question & Response \\
\hline Total number of residential green power participants & \\
\hline Total number of non-residential green power participants & \\
\hline Number of new residential green power participants in 2004 (do not subtract dropouts) & \\
\hline Number of new non-residential green power participants in 2004 (do not subtract dropouts) & \\
\hline Number of residential customers (or members) eligible to participate & \\
\hline Number of non-residential customers (or members) eligible to participate & \\
\hline Is the program currently open to new customers? Yes/No & \\
\hline Number of customers on waiting list & \\
\hline Number of participants who have dropped out of the program this year & \\
\hline Minimum period of time residential customers must participate (e.g., 1 year) & \\
\hline Minimum period of time non-residential customers must participate (e.g., 2 years) & \\
\hline
\end{tabular}

9. For programs that are offered to multiple distribution cooperatives or municipal utilities, please list any individual utilities that have achieved participation rates of 3\% or higher (please also note the participation rate). Utility:

Utility: Participation Rate:

Utility: Participation Rate:

Sales for 2004

10. In the table below, please indicate the sales of green power to customers during 2004.

\begin{tabular}{|l|l|l|l|}
\hline Green power sales for 2004 & \# Blocks Sold in 2004 & Block size & $\begin{array}{c}2004 \text { Sales } \\
(\mathrm{kWh})\end{array}$ \\
\hline Green power sales to residential customers & & & \\
\hline Green power sales to non-residential customers & & & \\
\hline Utility electricity sales to eligible residential customers & & & \\
\hline Utility electricity sales to eligible non-residential customers & & & \\
\hline
\end{tabular}


Renewable Energy Supplies

11. Of the renewable energy used to supply your program in 2004 , what percentage came from the following?

\begin{tabular}{|l|c|}
\hline Renewable projects owned or partially-owned by your utility & $\%$ \\
\hline Renewable energy purchases from others & $\%$ \\
\hline Renewable certificate purchases & $\%$ \\
\hline Total & $\%$ \\
\hline
\end{tabular}

12. In the table below, please indicate the type and amount of renewable resources used to supply participants in your green pricing program during 2004.

\begin{tabular}{|l|l|l|l|l|}
\hline $\begin{array}{l}\text { Name(s) of Renewable } \\
\text { Energy Project Used to }\end{array}$ & $\begin{array}{l}\text { Resource Type } \\
\text { (e.g.,. Wind, } \\
\text { PV) }\end{array}$ & $\begin{array}{l}\text { Nameplate } \\
\text { Capacity } \\
\text { Installed (kW) }\end{array}$ & $\begin{array}{l}\text { Year } \\
\text { Installed }\end{array}$ & $\begin{array}{l}\text { 2004 Energy or REC } \\
\text { Purchases (kWh/yr) }\end{array}$ \\
\hline & & & & \\
\hline & & & & \\
\hline & & & & \\
\hline & & & & \\
\hline
\end{tabular}

13. In the table below, please indicate any planned renewable energy projects that will be used to supply participants in your green pricing program.

\begin{tabular}{|l|l|l|}
\hline $\begin{array}{l}\text { Name(s) of Planned Renewable Energy } \\
\text { Projects to Supply Program in Future }\end{array}$ & $\begin{array}{l}\text { Nameplate Capacity } \\
\text { Planned (kW) }\end{array}$ & Year Planned \\
\hline & & \\
\hline & & \\
\hline
\end{tabular}

\section{Premium}

14. Please indicate the price premium charged for this green power product (i.e., $\$ / \mathrm{kWh}$ block, $\varnothing / \mathrm{kWh}$, $\$ / \mathrm{kW}$, or minimum suggested contribution)

15. Please indicate the premium for nonresidential customers, if different.

16. Was there a change in the premium in 2004 ? Yes/No

If so, why?

17. What is the minimum purchase for residential participants (e.g. 2 blocks or $25 \%$ of usage)?

18. What is the nonresidential minimum purchase (e.g. 100 blocks or $10 \%$ of usage)?

19. Are green power customers protected, by virtue of their green power purchase, from increases in fuel costs (i.e., natural gas) or non-renewable energy fees (i.e., emissions control fees)? Yes/No If so, how?

\section{Green Power Program Design and Implementation}

20. Have you performed (in 2004 or earlier) market research to aid in the design of your green power product or development of your marketing plan? Yes/No

If yes, in what year(s)?

What type of research was performed?

21. Have you performed an evaluation of the program (in 2004 or earlier)? Yes/No If yes, in what year(s)?

What aspect of the program was evaluated? 
22. In which of the following ways can customers sign up for your program? (check all that apply) Also, please rank the effectiveness of each method on a scale of 1 to 5 , with 5 being the most effective.

\begin{tabular}{|l|l|l|}
\hline & Check (x) & Rank (1-5) \\
\hline Utility Web site & & \\
\hline Checking a box on their electric bill & & \\
\hline Sign up at special events & & \\
\hline By returning a mail-in card & & \\
\hline By phone through the utility call center & & \\
\hline Other (please specify)? & & \\
\hline
\end{tabular}

23. What other value-added products or services do you provide to customers that enroll in your green power program? (check all that apply)

\begin{tabular}{|l|l|}
\hline Compact fluorescents or efficiency products & Decals for display in store windows \\
\hline Recognition of business customers in program ads or local media & Installations on schools/ education programs \\
\hline Discounts or promotions at local businesses & Plaques or other items for recognition \\
\hline Newsletters that provide program updates & Protection from fuel cost increases \\
\hline Tours to renewable energy project sites & Exemption from environmental fees \\
\hline Other (please list) & \\
\hline
\end{tabular}

\section{Marketing and Administration}

24. Please indicate below how much you spend annually on marketing the program, excluding staff time. (check the appropriate box below)

\begin{tabular}{|l|l|}
\hline Less than $\$ 10 \mathrm{k}$ & \\
\hline$\$ 11 \mathrm{k}-\$ 50 \mathrm{k}$ & \\
\hline$\$ 51 \mathrm{k}-\$ 100 \mathrm{k}$ & \\
\hline$\$ 101 \mathrm{k}-\$ 250 \mathrm{k}$ & \\
\hline$\$ 251 \mathrm{k}-\$ 500 \mathrm{k}$ & \\
\hline$\$ 501 \mathrm{k}-\$ 750 \mathrm{k}$ & \\
\hline$\$ 751 \mathrm{k}-\$ 1,000 \mathrm{k}$ & \\
\hline$>\$ 1,000 \mathrm{k}$ & \\
\hline
\end{tabular}

25. Please indicate below how much you spend annually on program administration, including staff time. (check the appropriate box below)

\begin{tabular}{|l|l|}
\hline Less than $\$ 10 \mathrm{k}$ & \\
\hline$\$ 11 \mathrm{k}-\$ 50 \mathrm{k}$ & \\
\hline$\$ 51 \mathrm{k}-\$ 100 \mathrm{k}$ & \\
\hline$\$ 101 \mathrm{k}-\$ 250 \mathrm{k}$ & \\
\hline$\$ 251 \mathrm{k}-\$ 500 \mathrm{k}$ & \\
\hline$\$ 501 \mathrm{k}-\$ 750 \mathrm{k}$ & \\
\hline$\$ 751 \mathrm{k}-\$ 1,000 \mathrm{k}$ & \\
\hline$>\$ 1,000 \mathrm{k}$ & \\
\hline
\end{tabular}

26. What percentage of your green power premium was attributable to marketing and administrative costs in 2004 ? $\%$

27. Are all program costs born by program participants? Yes/No If no, please explain

28. On average, how much did you spend in 2004 to sign up each residential customer (\$/customer)?

29. In the table below, please indicate which marketing strategies you used for your green power program in 2004 .

(check all that apply) Also, please rank the cost-effectiveness on a scale of 1 to 5 , with 5 being the most cost-

effective. 


\begin{tabular}{|l|l|l|l|l|l|}
\hline & Check (x) & Rank (1-5) & & Check (x) & Rank (1-5) \\
\hline Bill inserts & & & Publicity/feature stories (non-paid) & & \\
\hline Television & & & Events & & \\
\hline Telemarketing & & & Community challenges & & \\
\hline Direct mail & & Partner with environmental orgs. & & \\
\hline Radio & & Retail partners (co-branding) & & \\
\hline Billboards & & Web-based marketing & & \\
\hline Utility newsletter & & & Direct sales to commercial accts. & & \\
\hline Newspaper ads & & Kiosks & & \\
\hline Other (please list): & & & \\
\hline
\end{tabular}




\section{Appendix B - Utilities Offering Green Pricing Programs}

Table B-1: Utilities Offering Green Pricing Programs in 2004

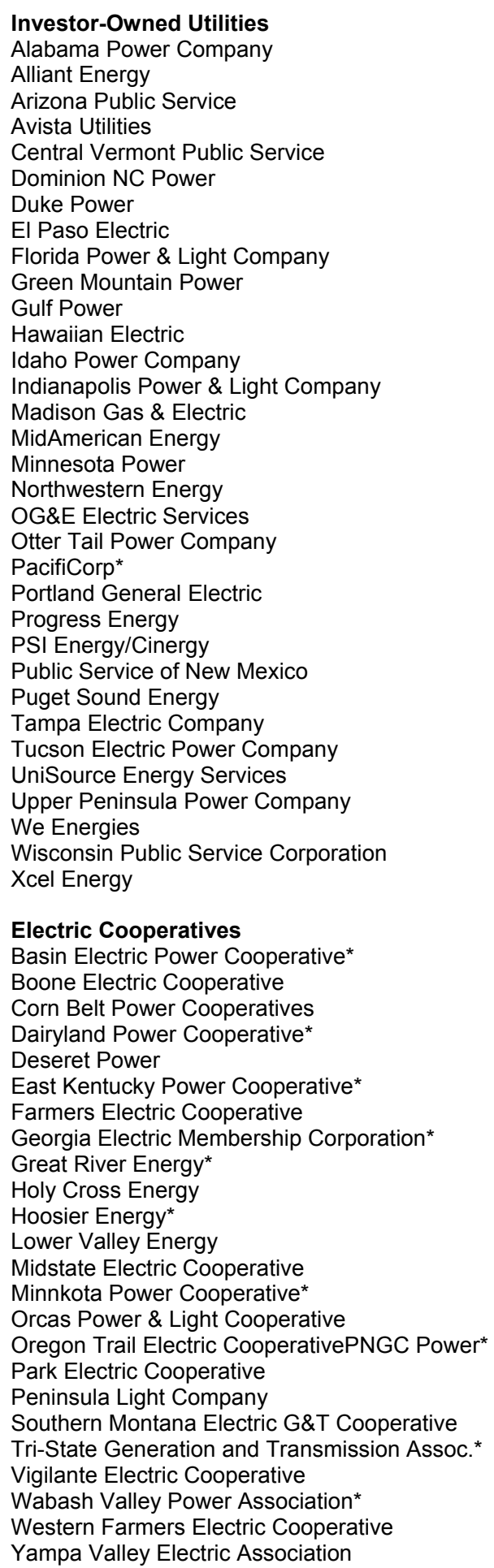

\section{Electric Cooperatives}

Basin Electric Power Cooperative*

Boone Electric Cooperative

Corn Belt Power Cooperatives

Dairyland Power Cooperative*

Deseret Power

East Kentucky Power Cooperative*

Farmers Electric Cooperative

Georgia Electric Membership Corporation*

Great River Energy*

Holy Cross Energy

Hoosier Energy*

Lower Valley Energy

Midstate Electric Cooperative

Minnkota Power Cooperative

Orcas Power \& Light Cooperative

Oregon Trail Electric CooperativePNGC Power*

Park Electric Cooperative

Peninsula Light Company

Southern Montana Electric G\&T Cooperative

Tri-State Generation and Transmission Assoc. *

Vigilante Electric Cooperative

Wabash Valley Power Association*

Western Farmers Electric Cooperative

Yampa Valley Electric Association

Federal

Tennessee Valley Authority*

Municipals/Other Public Utilities

City of Alameda

AMP Ohio

Anaheim Public Utilities

City of Ashland

Austin Energy

Benton County PUD

City of Bowling Green

Burbank Water and Power

Cedar Falls Utilities

Chelan County PUD

Clallum County PUD

Clark Public Utilities

Colorado Springs Utilities

Concord Municipal Light Plant

Cowlitz PUD

ElectriCities

Emerald People's Utility District

Eugene Water \& Electric Board

Gainsville Regional Utilities

Grant County PUD

Grays Harbor PUD

lowa Association of Municipal Utilities*

Keys Energy Services

Lansing Board of Water and Light

Lewis County PUD

Lincoln Electric System

Los Angeles Department of Water and Power

Mason County PUD No. 3

Missouri River Energy Services*

Moorhead Public Service

Muscatine Power and Water

City of New Smyrna Beach

Oklahoma Municipal Power Authority

Omaha Public Power District

Pacific County PUD \#2

Pasadena Water \& Power

City of Palo Alto Utilities

Platte River Power Authority*

Roseville Electric

Sacramento Municipal Utility District

City of St. Charles

Salt River Project

City Public Service of San Antonio

Santee Cooper*

Seattle City Light

Silicon Valley Power

Snohomish County PUD

Southern Minnesota Municipal Power Agency*

City Utilities of Springfield

Tacoma Power

City of Tallahassee

Traverse City Light \& Power

Waverly Light \& Power

Wisconsin Public Power Inc. *

*denotes program offered through multiple utilities or distribution cooperatives 


\section{Appendix C - Top 10 Utility Green Power Programs}

\section{Table C-1: Green Pricing Program Renewable Energy Sales \\ (as of December 2004)}

\begin{tabular}{|c|c|c|c|c|}
\hline Rank & Utility & Resources Used & $\begin{array}{c}\text { Sales } \\
(\mathrm{kWh} / \text { year) }\end{array}$ & $\begin{array}{l}\text { Sales } \\
(\text { aMW) }\end{array}$ \\
\hline 1 & Austin Energy & $\begin{array}{l}\text { Wind, landfill gas, } \\
\text { small hydro }\end{array}$ & $334,446,101$ & 38.2 \\
\hline 2 & Portland General Electric ${ }^{b}$ & $\begin{array}{l}\text { Existing geothermal, } \\
\text { wind, small hydro }\end{array}$ & $262,142,564$ & 29.9 \\
\hline 3 & PacifiCorp ${ }^{\text {cd }}$ & $\begin{array}{l}\text { Wind, biomass, } \\
\text { solar }\end{array}$ & $191,838,079$ & 21.9 \\
\hline 4 & Sacramento Municipal Utility District ${ }^{\mathrm{e}}$ & $\begin{array}{l}\text { Landfill gas, wind, } \\
\text { small hydro, solar }\end{array}$ & $176,774,804$ & 20.2 \\
\hline 5 & Xcel Energy & Wind & $137,946,000$ & 15.7 \\
\hline 6 & National Grid ${ }^{\text {fgh }}$ & $\begin{array}{l}\text { Biomass, wind, } \\
\text { small hydro, solar }\end{array}$ & $88,204,988$ & 10.1 \\
\hline 7 & $\begin{array}{l}\text { Los Angeles Department of Water \& } \\
\text { Power }\end{array}$ & $\begin{array}{l}\text { Wind and landfill } \\
\text { gas }\end{array}$ & $75,528,746$ & 8.6 \\
\hline 8 & OG\&E Electric Services & Wind & $56,672,568$ & 6.5 \\
\hline 9 & Puget Sound Energy & Wind, solar, biogas & $46,110,000$ & 5.3 \\
\hline 10 & We Energies ${ }^{e}$ & $\begin{array}{l}\text { Landfill gas, wind, } \\
\text { small hydro }\end{array}$ & $40,906,410$ & 4.7 \\
\hline
\end{tabular}

a An "average megawatt" (aMW) is a measure of capacity equivalent that assumes the capacity operates continuously.

${ }^{\mathrm{b}}$ Some products marketed in partnership with Green Mountain Energy Company.

${ }^{\mathrm{c}}$ Includes Pacific Power and Utah Power.

${ }^{\mathrm{d}}$ Some Oregon products marketed in partnership with 3 Phases Energy Services.

e Product is Green-e accredited (www.green-e.org).

${ }^{f}$ Includes Niagara Mohawk, Massachusetts Electric, Narragansett Electric, and Nantucket Electric.

${ }^{g}$ Marketed in partnership with Community Energy, CET \& Conservation Services Group, EnviroGen, Green Mountain Energy Company, Mass Energy, People's Power \& Light, and Sterling Planet.

${ }^{\mathrm{h}}$ Some products are Green-e certified (www.green-e.org). 

Table C-2: Total Number of Customer Participants
(as of December 2004)

\begin{tabular}{|c|c|c|c|}
\hline Rank & Utility & $\operatorname{Program}(\mathbf{s})$ & Participants \\
\hline 1 & Xcel Energy & $\begin{array}{l}\text { Windsource } \\
\text { Renewable Energy Trust }\end{array}$ & 40,990 \\
\hline 2 & PacifiCorp ${ }^{\text {ab }}$ & $\begin{array}{l}\text { Blue Sky Block } \\
\text { Blue Sky Usage } \\
\text { Blue Sky Habitat }\end{array}$ & 36,125 \\
\hline 3 & Portland General Electric ${ }^{c}$ & $\begin{array}{l}\text { Clean Wind } \\
\text { Green Source } \\
\text { Healthy Habitat }\end{array}$ & 33,491 \\
\hline 4 & Sacramento Municipal Utility District & $\begin{array}{l}\text { Greenergy } \\
\text { PV Pioneers I }\end{array}$ & 28,527 \\
\hline 5 & Los Angeles Department of Water \& Power & $\begin{array}{l}\text { Green Power for a Green } \\
L A\end{array}$ & 27,293 \\
\hline 6 & National Grid ${ }^{e}$ & GreenUp $p^{\mathrm{fg}}$ & 14,978 \\
\hline 7 & Puget Sound Energy & Green Power Program & 14,074 \\
\hline 8 & Alliant Energy & Second Nature ${ }^{d}$ & 11,544 \\
\hline 9 & We Energies & Energy for Tomorrow ${ }^{\mathrm{d}}$ & 11,120 \\
\hline 10 & Florida Power and Light $^{\mathrm{h}}$ & Sunshine Energy & 10,674 \\
\hline
\end{tabular}

a Includes Pacific Power and Utah Power.

${ }^{\mathrm{b}}$ Some Oregon products marketed in partnership with 3 Phases Energy Services.

${ }^{\mathrm{C}}$ Some products marketed in partnership with Green Mountain Energy Company.

${ }^{\mathrm{d}}$ Product is Green-e accredited (www.green-e.org).

e Includes Niagara Mohawk, Massachusetts Electric, Narragansett Electric, and Nantucket Electric.

f Marketed in partnership with Community Energy, CET \& Conservation Services Group, EnviroGen, Green Mountain Energy Company, Mass Energy, People's Power \& Light, and Sterling Planet.

${ }^{g}$ Some products are Green-e certified (www.green-e.org).

h Marketed in partnership with Green Mountain Energy Company. 
Table C-3: Customer Participation Rate

(as of December 2004)

\begin{tabular}{|c|c|c|c|c|}
\hline Rank & Utility & $\begin{array}{c}\text { Customer } \\
\text { Participation } \\
\text { Rate } \\
\end{array}$ & Program(s) & $\begin{array}{c}\text { Program } \\
\text { Start } \\
\text { Year } \\
\end{array}$ \\
\hline 1 & Lenox Municipal Utilities $^{a}$ & $14.5 \%$ & Green City Energy & 2003 \\
\hline 2 & City of Palo Alto Utilities ${ }^{b}$ & $10.9 \%$ & Palo Alto Green ${ }^{c}$ & 2003 \\
\hline 3 & $\begin{array}{l}\text { Montezuma Municipal Light \& } \\
\text { Power }^{a}\end{array}$ & $6.4 \%$ & Green City Energy & 2003 \\
\hline 4 & Holy Cross Energy & $5.2 \%$ & $\begin{array}{l}\text { Wind Power Pioneer } \\
\text { Local Renewable Energy } \\
\text { Pool }\end{array}$ & $\begin{array}{l}1998 \\
2002\end{array}$ \\
\hline 4 & Moorhead Public Service & $5.2 \%$ & Capture the Wind & 1998 \\
\hline 4 & $\begin{array}{l}\text { Sacramento Municipal Utility } \\
\text { District }\end{array}$ & $5.2 \%$ & $\begin{array}{l}\text { Greenergy } \\
\text { PV Pioneers I }\end{array}$ & $\begin{array}{l}1997 \\
1993\end{array}$ \\
\hline 7 & Orcas Power \& Light & $4.7 \%$ & Go Green & 1999 \\
\hline 8 & Portland General Electric ${ }^{d}$ & $4.3 \%$ & $\begin{array}{l}\text { Clean Wind } \\
\text { Green Source } \\
\text { Healthy Habitat }\end{array}$ & 2002 \\
\hline 9 & Central Electric Cooperative ${ }^{\mathrm{e}}$ & $4.0 \%$ & Green Power & 1999 \\
\hline 10 & Madison Gas \& Electric & $3.8 \%$ & Wind Energy Program & 1999 \\
\hline 10 & River Falls Municipal Utilities ${ }^{f}$ & $3.8 \%$ & $\begin{array}{l}\text { Renewable Energy } \\
\text { Program }\end{array}$ & 2001 \\
\hline
\end{tabular}

${ }^{\text {a }}$ Program offered in association with the lowa Association of Municipal Utilities.

${ }^{\mathrm{b}}$ Marketed in partnership with 3 Phases Energy Services

${ }^{\mathrm{c}}$ Product is Green-e accredited (www.green-e.org).

${ }^{\mathrm{d}}$ Some products marketed in partnership with Green Mountain Energy Company.

e Power supplied by PNGC Power.

${ }^{f}$ Program offered in association with Wisconsin Public Power Inc. 
Table C-4: Price Premium Charged for New, Customer-Driven Renewable Power ${ }^{a}$ (as of December 2004)

\begin{tabular}{|c|c|c|c|}
\hline Rank & Utility & Resources Used & $\begin{array}{c}\text { Premium } \\
\text { ( } \phi / \mathrm{kWh})\end{array}$ \\
\hline 1 & Avista Utilities & Wind & 0.33 \\
\hline 2 & Austin Energy ${ }^{b}$ & Wind, small hydro, landfill gas & 0.50 \\
\hline 3 & Edmond Electric $^{\mathrm{b}}$ & Wind & 0.68 \\
\hline 4 & Clallam County Public Utility District & Landfill gas & 0.70 \\
\hline 5 & Eugene Water and Electric Board ${ }^{\mathrm{b}}$ & Wind & 0.71 \\
\hline 6 & PacifiCorp ${ }^{c}$ & Wind, biomass, solar & 0.78 \\
\hline 7 & OG\&E Electric Services ${ }^{b}$ & Wind & 0.88 \\
\hline 8 & Wabash Valley Power Association ${ }^{d}$ & Landfill gas & 0.90 \\
\hline 9 & Roseville Electric & $\begin{array}{l}\text { Geothermal, small hydro, } \\
\text { solar }\end{array}$ & 1.00 \\
\hline 9 & Sacramento Municipal Utility District ${ }^{\mathrm{e}}$ & Landfill gas, wind, small hydro & 1.00 \\
\hline 9 & $\begin{array}{l}\text { Southern Minnesota Municipal Power } \\
\text { Agency }\end{array}$ & Wind & 1.00 \\
\hline
\end{tabular}

a Includes only programs that have installed or announced firm plans to install or purchase power from $100 \%$ new renewable resources.

${ }^{b}$ Premium is variable; customers in these programs are exempt or otherwise protected from changes in utility fuel charges.

${ }^{\mathrm{C}}$ Pacific Power product marketed in partnership with 3 Phases Energy Services

${ }^{\mathrm{d}}$ The premium charged by participating member distribution utilities varies from $0.9 \phi / \mathrm{kWh}$ to $1.0 \phi / \mathrm{kWh}$.

${ }^{\mathrm{e}}$ Product is Green-e accredited (www.green-e.org). 


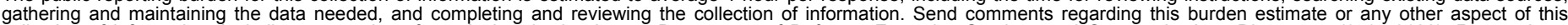

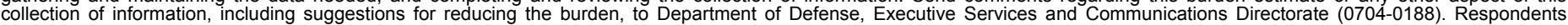

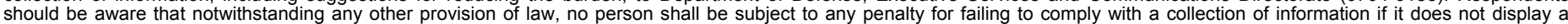

currently valid OMB control number.

PLEASE DO NOT RETURN YOUR FORM TO THE ABOVE ORGANIZATION.

\section{REPORT DATE (DD-MM-YYYY) October 2005 \\ 2. REPORT TYPE \\ Technical Report}

4. TITLE AND SUBTITLE

Trends in Utility Green Pricing Programs (2004)
3. DATES COVERED (From - To) 5a. CONTRACT NUMBER

DE-AC36-99-G010337

5b. GRANT NUMBER

5c. PROGRAM ELEMENT NUMBER

5d. PROJECT NUMBER

NREL/TP-620-38800

5e. TASK NUMBER

ASG5.1003

5f. WORK UNIT NUMBER

7. PERFORMING ORGANIZATION NAME(S) AND ADDRESS(ES)

National Renewable Energy Laboratory

1617 Cole Blvd.

Golden, CO 80401-3393

9. SPONSORING/MONITORING AGENCY NAME(S) AND ADDRESS(ES)

8. PERFORMING ORGANIZATION REPORT NUMBER

NREL/TP-620-38800

10. SPONSOR/MONITOR'S ACRONYM(S) NREL

11. SPONSORING/MONITORING AGENCY REPORT NUMBER

12. DISTRIBUTION AVAILABILITY STATEMENT

National Technical Information Service

U.S. Department of Commerce

5285 Port Royal Road

Springfield, VA 22161

13. SUPPLEMENTARY NOTES

14. ABSTRACT (Maximum 200 Words)

In the early 1990s, only a handful of utilities offered their customers a choice of purchasing electricity generated from renewable energy sources. Today, nearly 600 utilities in regulated electricity markets-or almost $20 \%$ of all utilities nationally_provide their customers a "green power" option. Because some utilities offer programs in conjunction with cooperative associations or other publicly owned power entities, the number of distinct programs totals about 125. Through these programs, more than 40 million customers spanning 34 states have the ability to purchase renewable energy to meet some portion or all of their electricity needs-or make contributions to support the development of renewable energy resources. Typically, customers pay a premium above standard electricity rates for this service. This report presents year-end 2004 data on utility green pricing programs, and examines trends in consumer response and program implementation over time. The data in this report, which were obtained via a questionnaire distributed to utility green pricing program managers, can be used by utilities as benchmarks by which to gauge the success of their green power programs.

15. SUBJECT TERMS

Green power; green pricing; utilities; electricity customers; public power; renewable energy supplies; renewable energy certificates; RECs; green power products; customer-acquisition costs; marketing costs; Lori Bird; Elizabeth Brown

\begin{tabular}{|c|c|c|}
\hline $\begin{array}{l}\text { a. REPORT } \\
\text { Unclassified }\end{array}$ & $\begin{array}{l}\text { b. ABSTRACT } \\
\text { Unclassified }\end{array}$ & $\begin{array}{l}\text { c. THIS PAGE } \\
\text { Unclassified }\end{array}$ \\
\hline
\end{tabular}

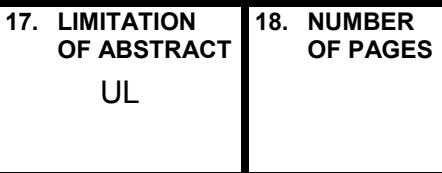

19a. NAME OF RESPONSIBLE PERSON

19b. TELEPHONE NUMBER (Include area code) 